\title{
The Eminent Role of microRNAs in the Pathogenesis of Alzheimer's Disease
}

\author{
Mohammad Samadian ${ }^{1 \dagger}$, Mahdi Gholipour ${ }^{2 \dagger}$, Mohammadreza Hajiesmaeili ${ }^{1 \dagger}$, \\ Mohammad Taheri ${ }^{3 * \dagger}$ and Soudeh Ghafouri-Fard ${ }^{4 * t}$
}

1 Skull Base Research Center, Loghman Hakim Hospital, Shahid Beheshti University of Medical Sciences, Tehran, Iran, ${ }^{2}$ Department of Medical Genetics, Shahid Beheshti University of Medical Sciences, Tehran, Iran, ${ }^{3}$ Urology and Nephrology Research Center, Shahid Beheshti University of Medical Sciences, Tehran, Iran, ${ }^{4}$ Urogenital Stem Cell Research Center, Shahid Beheshti University of Medical Sciences, Tehran, Iran

\section{OPEN ACCESS}

Edited by:

Ramesh Kandimalla,

Texas Tech University Health Sciences

Center, United States

Reviewed by:

Rezvan Noroozi,

Jagiellonian University, Poland

Santosh Jadhav,

Institute of Neuroimmunology

(SAS), Slovakia

${ }^{*}$ Correspondence:

Mohammad Taheri

mohammad_823@yahoo.com

Soudeh Ghafouri-Fard

s.ghafourifard@sbmu.ac.ir

†These authors have contributed equally to this work

Received: 13 December 2020 Accepted: 19 February 2021 Published: 15 March 2021

Citation:

Samadian M, Gholipour M,

Hajiesmaeili $M$, Taheri $M$ and Ghafouri-Fard S (2021) The Eminent Role of microRNAs in the

Pathogenesis of Alzheimer's Disease.

Front. Aging Neurosci. 13:641080.

doi: 10.3389/fnagi.2021.641080
Alzheimer's disease (AD) is an irrevocable neurodegenerative condition characterized by the presence of senile plaques comprising amassed $\beta$-amyloid peptides (A $\beta$ ) and neurofibrillary tangles mainly comprising extremely phosphorylated Tau proteins. Recent studies have emphasized the role of microRNAs (miRNAs) in the development of $\mathrm{AD}$. A number of miRNAs, namely, miR-200a-3p, miR-195, miR-338-5p, miR-34a-5p, miR-125b-5p, miR-132, miR-384, miR-339-5p, miR-135b, miR-425-5p, and miR-339-5p, have been shown to participate in the development of AD through interacting with BACE1. Other miRNAs might affect the inflammatory responses in the course of AD. Aberrant expression of several miRNAs in the plasma samples of AD subjects has been shown to have the aptitude for differentiation of $A D$ subjects from healthy subjects. Finally, a number of AD-modifying agents affect miRNA profile in cell cultures or animal models. We have performed a comprehensive search and summarized the obtained data about the function of miRNAs in AD in the current review article.

Keywords: Alzheimer's disease, miRNA, marker, expression, polymorphism

\section{INTRODUCTION}

Alzheimer's disease $(\mathrm{AD})$ is an irrevocable neurodegenerative condition with a progressive course, and it is the chief reason for dementia in the elderly (Prince et al., 2013). AD is characterized by pervasive cognitive defects and memory deficits, leading to the dependence of the majority of $A D$ patients on others for their routine activities. From a pathological point of view, $\mathrm{AD}$ is defined by the presence of senile plaques comprising amassed $\beta$-amyloid peptides (A $\beta)$ and neurofibrillary tangles mainly comprising extremely phosphorylated Tau proteins (Ballard et al., 2011). The most accepted hypotheses for the development of $\mathrm{AD}$ are based on these two main pathological events [i.e., $A \beta$ accumulation and Tau accumulation (Wang et al., 2019a)]. The amyloid precursor protein is converted to $A \beta$ through consecutive enzymatic reactions catalyzed by $\beta$-secretase (BACE1) and $\gamma$-secretase (containing presenilin 1 and presenilin 2) (Querfurth and LaFerla, 2010). Recent studies have emphasized the role of microRNAs (miRNAs) in the development of AD (Wang et al., 2019a). These $\sim 22$ nucleotide transcripts post-transcriptionally regulate the expression of several target genes through binding with 3' UTR and destructing the target transcript or reducing its translation (O'Brien et al., 2018). Sequence complementarity mainly regulates the miRNA/mRNA interactions leading to the ability of one miRNA to target several genes and the possible regulation of one gene by multiple miRNAs. Therefore, miRNAs are potential means for investigating multifactorial 
disorders such as AD (Iqbal and Grundke-Iqbal, 2010). A leading investigation in this regard has examined the number of brain-associated miRNAs expressed in the human hippocampus specimens obtained from fetal, adult, and $\mathrm{AD}$ patients, revealing misregulation of certain miRNAs in the AD brain and their possible contribution to the pathological processes of this disorder (Lukiw, 2007). Dysregulation of other miRNAs has also been verified in multiple studies, and the underlying mechanisms of their contribution in $\mathrm{AD}$ have been identified in some cases. We have performed a comprehensive search and summarized the obtained data about the function of miRNAs in $\mathrm{AD}$ in this review article.

\section{DYSREGULATED MIRNAS IN AD}

Dysregulation of miRNAs has been demonstrated in human $\mathrm{AD}$ subjects or animal models of $\mathrm{AD}$. Moreover, several researchers have induced or suppressed the expression of some miRNAs in the cell/animal models of $\mathrm{AD}$ to appraise their function in the progression of $\mathrm{AD}$. In a rat model of $\mathrm{AD}$ caused by the administration of $\mathrm{A} \beta_{25-35}$ into the brain, downregulation of SOX6 and over-expression of miR-129-5p have shortened the dormant escape period and enhanced the time of crossing platforms, repairing the pathological damage, blocking neuronal apoptosis, and decreasing inflammation. Based on the protective effects of miR-129-5p against nerve damage and inflammation, miR-129-5p has been suggested as a candidate for therapeutic options against $\mathrm{AD}$, as it acts to suppress SOX6 (Zeng et al., 2019). Expression of miR200a-3p has been shown to be repressed in animal and cell models of AD. miR-200a-3p can suppress cell apoptosis, inactivate $\mathrm{Bax} /$ caspase- 3 axis, and decrease $\mathrm{A} \beta_{1-42}$ and tau phosphorylation in cell experiments. Mechanistically, these effects are mediated through the modulation of translocation of BACE1 and PRKACB. Taken together, the neuroprotective impact of miR-200a-3p is accomplished by inhibition of BACE1 expression and subsequent suppression of $A \beta$ production as well as reduction of PKA expression and Tau phosphorylation (Wang et al., 2019b). miR-455-3p has been shown to bind with 3' UTR of APP gene to decrease its expression and reduce expression of mitochondrial fission proteins (Kumar et al., 2019). Mutant APP cells that show expression of miR-455-3p exhibit upregulation of synaptic genes. Over-expression of miR-455-3p in mutant APP cells reduces the number of mitochondria and increases the size of the mitochondria. Taken together, miR-455$3 \mathrm{p}$ controls APP processing and protects against mutant APPassociated mitochondrial dysfunction and synaptic anomalies in AD (Kumar et al., 2019). Expression of miR-455-3p has been shown to be increased in postmortem brain samples, fibroblasts, and plasma samples of patients with $\mathrm{AD}$ compared with controls

Abbreviations: AD, Alzheimer's disease; microRNA, miRNA; $A \beta, \beta$-amyloid peptides; BACE1, $\beta$-secretase; EOAD, early-onset Alzheimer's disease; CNV, copy number variant; SNP, single nucleotide polymorphism; AChE, Acetylcholinesterase; iNOS, Inducible nitric oxide synthase; ROS, reactive oxygen species; MDA, Malondialdehyde; MAPK, mitogen-activated protein kinase; SOD, Superoxide dismutase; GSH-Px, glutathione peroxidase.
(Kumar et al., 2017; Kumar and Reddy, 2018). As a primary event, expression of miR-409-5p has been decreased in an APP/PS1 double transgenic mice model of AD. Over-expression experiments have shown that this miRNA has a harmful impact on neurite outgrowth, reduces neuron survival, and quickens the progression of $A \beta_{1-42}$-associated pathologic events (Guo et al., 2019). In line with the observed downregulation of miR-409$5 p$ in APP/PS1 AD model, $A \beta_{1-42}$ peptide has been shown to downregulate miR-409-5p levels. A luciferase study has shown that Plek is a target of miR-409-5p (Guo et al., 2019). Ectopic expression of miR-409-5p has induced neurotoxic effects and interferes with neuron survival and differentiation, while Plek upregulation could partly protect the neurite outgrowth from these toxic effects. Taken together, reduction of miR-409-5p expression in the early stages of $\mathrm{AD}$ might be a self-protective response to lessen the synaptic injury induced by $A \beta$ (Guo et al., 2019). miR-132 is another downregulated miRNA in AD. Experiments in a rat model of $\mathrm{AD}$ have shown upregulation of AChE, iNOS, ROS, MDA, MAPK1, and p-MAPK1 and downregulation of SOD, GSH-Px, and miR-132. Over-expression of miR-132 has reversed these markers demonstrating the role of this miRNA in the suppression of hippocampal iNOS expression and oxidative stress through reduction of MAPK1 levels (Deng et al., 2020). However, expression of this miRNA has been demonstrated to be reduced in neurally-originated plasma exosomes of AD subjects (Cha et al., 2019). Table 1 shows the summary of studies that reported decreased levels of miRNAs in AD.

Although several studies have reported downregulation of miR-132 in AD (Wong et al., 2013; El Fatimy et al., 2018; Cha et al., 2019; Deng et al., 2020), Liu et al. have reported high levels of miR-132 in patients with mild cognitive impairment and AD vs. normal individuals. They have shown the impact of miR-132 upregulation in the induction of apoptosis in neurons through increasing Bax/Bcl-2 ratio (Liu and Zhang, 2019). Moreover, they have reported that miR-132 increases Tau phosphorylation and expression levels of Rb, Histone $\mathrm{H} 1$, and CDK-5. Collectively, they have suggested that miR-132 participates in $\mathrm{AD}$ by controlling cell apoptosis and the GTDC-1/CDK-5/Tau phosphorylation axis (Liu and Zhang, 2019). In addition to GTDC-1, miR-132 is also known to regulate the expression of synaptic proteins via complement C1q (Xu et al., 2019). Similarly, expression of miR-132 has been shown to be decreased in AD-derived plasma exosomes (Cha et al., 2019). miR-128 has also been over-expressed in the brain samples of $\mathrm{AD}$ patients (Liu et al., 2019). Experiments in AD mice have demonstrated parallel upregulation of miR-128 and downregulation of PPAR $\gamma$ in the cerebral cortex. The interaction between these two transcripts has been validated through functional assays. miR128 silencing has suppressed $\mathrm{AD}$-like features, amyloid plaque creation, $\mathrm{A} \beta$ production, and inflammation in $\mathrm{AD}$ mice through upregulating PPAR $\gamma$ (Liu et al., 2019). miR-425-5p is another upregulated miRNA in patients with $\mathrm{AD}$ and the cellular model of AD. Upregulation of miR-425-5p has induced cell apoptosis, stimulated expression of GSK-3 $\beta$, and enhanced tau phosphorylation through targeting HSPB8 (Yuan et al., 2020). miR-146a is also upregulated in $\mathrm{AD}$ and participates in the 
TABLE 1 | Downregulated miRNAs in AD subject, animal models of AD, and related cell lines and their functions in progression of AD.

\begin{tabular}{|c|c|c|c|c|c|c|}
\hline microRNA & Samples & $\begin{array}{l}\text { Assessed cell } \\
\text { line }\end{array}$ & $\begin{array}{l}\text { Gene/protein } \\
\text { interaction }\end{array}$ & $\begin{array}{l}\text { Signaling } \\
\text { pathway }\end{array}$ & Function & References \\
\hline miR-129-5p & $\begin{array}{l}90 \text { male-specific pathogen-free (SPF) } \\
\text { Sprague-Dawley (SD) rats }\end{array}$ & $\begin{array}{l}\text { Hippocampal } \\
\text { neuron cells of rat }\end{array}$ & sox6 & - & $\begin{array}{l}\text { Its upregulation represses apoptosis and inflammatory reactions } \\
\text { and attenuates neural injury by targeting SOX6. }\end{array}$ & Zeng et al., 2019 \\
\hline miR-200a-3p & $\begin{array}{l}\text { Plasma samples from } 7 \text { patients with } \\
\text { AD and } 5 \text { age-matched healthy } \\
\text { individual, APP/PS1 mice, SAMP8, } \\
\text { and SAMR1 mice }\end{array}$ & NB-1 & BACE1, PRKACB & - & $\begin{array}{l}\text { Has neuroprotective effects, suppresses apoptosis, and } \\
\text { decreases A } \beta \text { production through regulating expression of BACE1 } \\
\text { and PRKACB }\end{array}$ & Wang et al., 2019b \\
\hline miR-326 & $\begin{array}{l}\text { APPswe/PS1d E9 double transgenic } \\
\text { mouse }\end{array}$ & - & VAV1 & $\begin{array}{l}\text { JNK signaling } \\
\text { pathway }\end{array}$ & $\begin{array}{l}\text { Its overexpression decreased neuronal apoptosis and A } \beta \\
\text { accumulation and elevated viability of neuron cells by targeting } \\
\text { VAV1. }\end{array}$ & He et al., 2020 \\
\hline miR-98 & 70 Kunming mice & $\begin{array}{l}\text { Hippocampal } \\
\text { neuronal cells }\end{array}$ & HEY2 & $\begin{array}{l}\text { Notch signaling } \\
\text { pathway }\end{array}$ & $\begin{array}{l}\text { Represses apoptosis of hippocampal neurons and shows } \\
\text { enhanced survival of these cells by targeting HEY2 and } \\
\text { inactivating the Notch signaling pathway }\end{array}$ & Chen et al., 2019 \\
\hline miR-196a & 60 male Sprague-Dawley mice & HEK-293T & LRIG3 & PI3/Akt pathway & $\begin{array}{l}\text { Its upregulation ameliorated cognitive decline, inhibited apoptosis, } \\
\text { and increased survival of neurons by targeting LRIG3. }\end{array}$ & Yang et al., 2019a \\
\hline miR-195 & 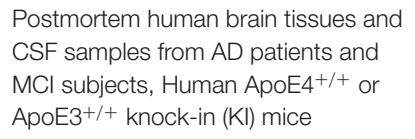 & $\begin{array}{l}\text { Mouse primary } \\
\text { neuron }\end{array}$ & synj1 & - & $\begin{array}{l}\text { Its overexpression alleviated cognitive impairment and decreased } \\
A \beta \text { deposition and tau hyper-phosphorylation. }\end{array}$ & Cao et al., 2020 \\
\hline miR-195 & SAMP8 and SAMR1 mice & HEK293, N2a & BACE1 & - & $\begin{array}{l}\text { Its overexpression reduced A } \beta \text { production through targeting } \\
\text { BACE1. }\end{array}$ & Zhu et al., 2012 \\
\hline miR-338-5p & $\begin{array}{l}\text { Hippocampal tissue samples from } \\
\text { patients with } A D \text { and normal subjects, } \\
\text { 5XFAD transgenic (TG) mice }\end{array}$ & - & BACE1 & $\begin{array}{l}\text { NF-кB signaling } \\
\text { pathway }\end{array}$ & $\begin{array}{l}\text { Its overexpression prevented A formation, neuroinflammation, } \\
\text { cognitive deficit and impaired learning ability by targeting BACE1. }\end{array}$ & Qian et al., 2019 \\
\hline miR-338-5p & $\begin{array}{l}\text { Male C57BL/6 mice and male } \\
\text { APP/PS1 transgenic mice }\end{array}$ & $\begin{array}{l}\text { Primary } \\
\text { hippocampal } \\
\text { neurons }\end{array}$ & BCL2L11 & - & $\begin{array}{l}\text { Its overexpression prevented A } \beta \text { deposition, cognitive decline, and } \\
\text { reduced apoptosis rate of neurons by targeting BCL2L11. }\end{array}$ & Li et al., 2020a \\
\hline $\operatorname{miR}-133 b$ & $\begin{array}{l}\text { Serum samples from } 105 \mathrm{AD} \text { patients } \\
\text { and } 98 \text { control individuals }\end{array}$ & SH-SY5Y & EGFR & - & $\begin{array}{l}\text { Its overexpression reduced apoptosis rate and improved cell } \\
\text { viability. }\end{array}$ & Wang et al., 2019c \\
\hline miR-124 & Male APP/PS1 transgenic mice & - & $\mathrm{C} 1 \mathrm{ql} 3$ & - & $\begin{array}{l}\text { Its overexpression increased angiogenesis and lowered the } \\
\text { accumulation of } A \beta \text { and prevented memory decline and learning } \\
\text { impairment. }\end{array}$ & Zhang et al., 2019 \\
\hline$m i R-124-3 p$ & - & $\begin{array}{l}\text { N2a/APP695swe } \\
\text { cells }\end{array}$ & Caveolin-1 & $\begin{array}{l}\mathrm{PI3K} / A K t / G S K 3 \beta \\
\text { pathway }\end{array}$ & $\begin{array}{l}\text { Its upregulation abated Tau hyperphosphorylation and cellular } \\
\text { apoptosis by targeting Caveolin-1 and modulation of } \\
\text { PI3K/Akt/GSK3 } \beta \text { pathway. }\end{array}$ & Kang et al., 2017 \\
\hline miR-101a & $\begin{array}{l}\text { Plasma samples from } 46 \mathrm{AD} \text { patients } \\
60 \text { healthy individuals, APPswe/ } \\
\text { PS1 } \triangle \mathrm{E} 9 \text { transgenic mice }\end{array}$ & SH-SY5Y & MAPK1 & MAPK pathway & $\begin{array}{l}\text { Regulates autophagy through targeting MAPK1 and modulating } \\
\text { the MAPK pathway }\end{array}$ & Xiao et al., 2019 \\
\hline miR-22 & $\begin{array}{l}\text { Serum samples from } 33 \text { patients with } \\
\text { AD and } 30 \text { healthy volunteers, } \\
\text { APP/PS1 double transgenic mice }\end{array}$ & MG cells & GSDMD & - & $\begin{array}{l}\text { Its overexpression suppressed secretion of inflammatory factors } \\
\text { and pyroptosis also decreased GSDMD expression. }\end{array}$ & Han et al., 2020 \\
\hline miR-34a & - & SH-SY5Y & Caspase-2 & - & $\begin{array}{l}\text { Its upregulation suppressed neurotoxicity induced by } A \beta \text { through } \\
\text { targeting Caspase- } 2 \text {. }\end{array}$ & Wang et al., 2019c \\
\hline
\end{tabular}


TABLE 1 | Continued

\begin{tabular}{|c|c|c|c|c|}
\hline microRNA & Samples & $\begin{array}{l}\text { Assessed cell } \\
\text { line }\end{array}$ & $\begin{array}{l}\text { Gene/protein } \\
\text { interaction }\end{array}$ & $\begin{array}{l}\text { Signaling } \\
\text { pathway }\end{array}$ \\
\hline miR-34a & APP/PS1 transgenic mice & $\begin{array}{l}\text { SH-SY5Y, primary } \\
\text { cortical neuronal } \\
\text { cells }\end{array}$ & cyclin D1 & - \\
\hline $\begin{array}{l}\text { miR-34a-5p } \\
\text { miR-125b-5p }\end{array}$ & $\begin{array}{l}\text { Serum samples from } 27 \mathrm{AD} \text { patients } \\
\text { and } 27 \text { age-matched control } \\
\text { individuals }\end{array}$ & N2a, MCN & BACE1 & - \\
\hline miR-181a & $\begin{array}{l}\text { APP/PS1 transgenic mice and male } \\
\text { wild-type C67BL/6J mice }\end{array}$ & $\begin{array}{l}\text { Murine brain } \\
\text { pericytes }\end{array}$ & FOXO1 & - \\
\hline miR-31 & Female AD triple-transgenic mice & $\begin{array}{l}\text { HT-22, HEK293, } \\
\text { SH-SY5Y }\end{array}$ & APP & - \\
\hline$m i R-409-5 p$ & $\begin{array}{l}\text { APPswe/PS1 } \triangle \text { E9 double transgenic } \\
\text { mice }\end{array}$ & $\begin{array}{l}\text { PC12, Neuro2A, } \\
\text { HEK293T }\end{array}$ & Plek & - \\
\hline miR-107 & $\begin{array}{l}\text { CSF samples from } 22 \mathrm{AD} \text { patients } \\
\text { and } 10 \text { healthy controls }\end{array}$ & SH-SY5Y & FGF7 & $\begin{array}{l}\text { FGFR2/PI3K/Akt } \\
\text { pathway }\end{array}$ \\
\hline miR-107 & - & $\begin{array}{l}\text { hCMEC/D3, NHA, } \\
\text { HBVP }\end{array}$ & Endophilin-1 & - \\
\hline $\begin{array}{l}\text { miR-107 } \\
\text { miR-103 }\end{array}$ & $\begin{array}{l}\text { Post-mortem brain tissues from } 12 \\
\text { AD patients and } 12 \text { age- and } \\
\text { gender-matched control individuals }\end{array}$ & $\begin{array}{l}\text { SK-N-BE, } \\
\text { HEK-293 }\end{array}$ & CDK5R1 & - \\
\hline miR-212 & $\begin{array}{l}\text { Plasma sample from } 31 \text { AD patients } \\
\text { and } 31 \text { control subjects }\end{array}$ & SH-SY5Y, IMR-32 & PDCD4 & $\begin{array}{l}\text { PI3K/AKT } \\
\text { signaling pathway }\end{array}$ \\
\hline miR-433 & $\begin{array}{l}\text { Serum samples from } 118 \text { AD patients } \\
\text { and } 62 \text { healthy controls }\end{array}$ & $\begin{array}{l}\text { SH-SY5Y, } \\
\text { SK-N-SH }\end{array}$ & JAK2 & - \\
\hline miR-132 & 70 SPF Sprague-Dawley rats & HEK 293T & MAPK1 & $\begin{array}{l}\text { MAPK1 signal } \\
\text { pathway }\end{array}$ \\
\hline miR-132 & P301S Tau transgenic mice & $\begin{array}{l}\text { Primary cortical } \\
\text { and hippocampal } \\
\text { neuron cultures }\end{array}$ & $\begin{array}{l}\text { Rbfox1, GSK3 } \beta \text {, } \\
\text { EP300, Calpain } 2\end{array}$ & - \\
\hline $\begin{array}{l}\text { miR-132 } \\
\text { miR-212 }\end{array}$ & $\begin{array}{l}\text { Human post-mortem brain tissues } \\
\text { from } 10 \mathrm{AD} \text { patients and } 6 \text { control } \\
\text { subjects }\end{array}$ & $\begin{array}{l}\text { Primary human } \\
\text { neurons, SH-SY5Y }\end{array}$ & NOS1 & - \\
\hline $\begin{array}{l}\text { miR-132 } \\
\text { miR-212 }\end{array}$ & $\begin{array}{l}\text { Brain tissues from } 29 \text { AD patients and } \\
16 \text { controls }\end{array}$ & $\begin{array}{l}\text { PC12, primary } \\
\text { neurons }\end{array}$ & $\begin{array}{l}\text { PTEN, FOXO3a, } \\
\text { P300 }\end{array}$ & $\begin{array}{l}\text { AKT signaling } \\
\text { pathway }\end{array}$ \\
\hline miR-132 & $\begin{array}{l}\text { Post-mortem brain tissues from AD } \\
\text { patients, } 3 \times T g-A D \text { mice lacking the } \\
\text { miR-132/212 cluster }\end{array}$ & $\begin{array}{l}\text { Neuro2a, Neuro2a } \\
\text { APPSwe/A9, } \\
\text { HEK293T, } \\
\text { HEK293-APPSwe }\end{array}$ & Sirt1 & - \\
\hline miR-132 & $\begin{array}{l}\text { Brain tissues from AD patients and } \\
\text { normal controls, APPPS1 mice }\end{array}$ & HEK293-APPswe & ITPKB & - \\
\hline
\end{tabular}

Function

References

Regulates apoptosis rate and neuronal cell cycle by targeting cyclin D1

Their overexpression ameliorated oxidative stress and apoptosis induced by A $\beta$ through targeting BACE1.

Its overexpression alleviated cognitive decline, reduced accumulation of $A \beta$, and slowed pericyte loss by targeting FOXO1. Its overexpression reduced $A \beta$ accumulation and alleviated neuropathology of $A D$ and memory impairment.

Its overexpression expression aggravated cell survival and differentiation and impaired neurite outgrowth by targeting Plek.

Its upregulation reduced apoptosis and inflammation also elevated proliferation of SH-SY5Y through regulation of

FFF/FGFR2/PI3K/Akt Pathway induced by A $\beta$.

Its overexpression inhibited disruption of the blood-brain barrier induced by $A \beta$ and alleviated impaired function of endothelial cells by targeting Endophilin-1.

Can be implicated in $\mathrm{AD}$ pathogenesis through regulation of CDK5R1 expression and consequently influencing p53 levels

Reduces neurotoxicity of A $\beta$ by targeting PDCD4 regulation of PI3K/AKT signaling pathway

Its overexpression improved the viability of neurons by targeting JAK2. Its expression is associated with MMSE scores.

Modi et al., 2016

Suppresses oxidative stress and alleviated cognitive performance by targeting MAPK1

Has neuroprotective effects including reduces neurotoxicity of $A \beta$ and improves elongation of neurite and decreases neuronal death through targeting Rbfox1, GSK3 $\beta$, EP300, and Calpain 2

Low expression of miR-132 and miR-212 disrupted the balance of Wang et al., 2017 S-nitrosylation through modulation of NOS1 expression.

Regulates survival and apoptosis of neuronal cells through targeting PTEN, FOXO3a, and P300.

Its deletion was associated with increased $A \beta$ production and the establishment of amyloid plaque.

Wu et al., 2019

Barros-Viegas

et al., 2020

Guo et al., 2019

Chen et al., 2020a

Liu et al., 2016a

Moncini et al.,

017

Chang, 2020

Wang and Zhang 2020

Deng et al., 2020

El Fatimy et al., 2018

Wong et al., 2013

Hernandez-Rapp et al., 2016

Regulates $A B$ formation and TAU phosphorylation through targeting ITPKB and modulation of ERK1/2 and BACE1 activity. 
TABLE 1 | Continued

\begin{tabular}{|c|c|c|c|c|c|c|}
\hline microRNA & Samples & $\begin{array}{l}\text { Assessed cell } \\
\text { line }\end{array}$ & $\begin{array}{l}\text { Gene/protein } \\
\text { interaction }\end{array}$ & $\begin{array}{l}\text { Signaling } \\
\text { pathway }\end{array}$ & Function & References \\
\hline miR-9-5p & - & HT22 & GSK-3 $\beta$ & $\begin{array}{l}\text { Nrf2/Keap1 } \\
\text { signaling }\end{array}$ & 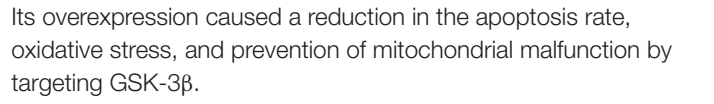 & Liu et al., 2020 \\
\hline miR-377 & - & SH-SY5Y & $\mathrm{CDH} 13$ & - & $\begin{array}{l}\text { Its upregulation enhanced cell proliferation and prevented } \\
\text { occurrence apoptosis by targeting } \mathrm{CDH} 13 \text {. }\end{array}$ & Liu et al., 2018 \\
\hline miR-221 & $\begin{array}{l}\text { Blood samples from } 21 \mathrm{AD} \text { patients } \\
\text { and } 17 \text { controls }\end{array}$ & SH-SY5Y & ADAM10 & - & $\begin{array}{l}\text { Can be implicated in AD pathogenesis through regulation of } \\
\text { ADAM10 expression }\end{array}$ & $\begin{array}{l}\text { Manzine et al., } \\
2018\end{array}$ \\
\hline miR-186 & 72 male Sprague-Dawley (SD) rats & $\begin{array}{l}\text { Hippocampal } \\
\text { neuronal cells }\end{array}$ & IL2 & $\begin{array}{l}\text { JAK-STAT } \\
\text { signaling pathway }\end{array}$ & $\begin{array}{l}\text { Its upregulation inhibited apoptosis and enhanced cell proliferation } \\
\text { through targeting IL2 and regulation of the JAK-STAT signaling } \\
\text { pathway. }\end{array}$ & Wu et al., 2018a \\
\hline miR-330 & 14 C57 mice & $\begin{array}{l}\text { Primary neuron } \\
\text { cells obtained from } \\
\text { mice }\end{array}$ & VAV1 & $\begin{array}{l}\text { MAPK signaling } \\
\text { pathway }\end{array}$ & $\begin{array}{l}\text { Its overexpression reduced oxidative stress, ameliorated } \\
\text { mitochondrial dysfunction, and decreased the generation of } A \beta \text { by } \\
\text { targeting VAV1. }\end{array}$ & Han et al., 2018 \\
\hline let-7f-5p & $\begin{array}{l}\text { C57BL/6J-TgN (APP/PS1) ZLFILAS } \\
\text { mice }\end{array}$ & $\begin{array}{l}\text { Bone marrow } \\
\text { mesenchymal } \\
\text { stem cells }\end{array}$ & Caspase-3 & - & $\begin{array}{l}\text { Its overexpression inhibited apoptosis induced by A } \beta \text { through } \\
\text { targeting caspase- } 3 \text {. It also increased the survival rate of MSCs in } \\
\text { mouse brain. }\end{array}$ & Shu et al., 2018 \\
\hline miR-107 & 60 male C57 mice & - & - & - & $\begin{array}{l}\text { Its overexpression alleviated spatial memory dysfunction, } \\
\text { hippocampal long-term potentiation and prevented the elimination } \\
\text { of pyramidal neurons induced resulted from neurotoxicity of } A \beta \text {. }\end{array}$ & Shu et al., 2018 \\
\hline $\begin{array}{l}\text { miRNA-140- } \\
5 p\end{array}$ & $\begin{array}{l}\text { Post mortem brain tissues from } 21 \\
\text { AD patients and } 22 \text { normal subjects }\end{array}$ & SHSY5Y, CHP212 & ADAM10, SOX2 & - & $\begin{array}{l}\text { Is implicated in AD pathogenesis through targeting ADAM10 and } \\
\text { its transcription factor SOX2 }\end{array}$ & Akhter et al., 2018 \\
\hline miR-384 & $\begin{array}{l}\text { Serum and CSF samples from } 32 \\
\text { MCl patients, } 45 \text { AD patients, and } 50 \\
\text { control individuals }\end{array}$ & SH-SY5Y, HEK293 & BACE-1, APP & - & $\begin{array}{l}\text { Its overexpression decreased the expression of BACE-1 and APP } \\
\text { so it can contribute to AD pathogenesis. }\end{array}$ & Liu et al., 2014b \\
\hline miR-188-5p & $\begin{array}{l}\text { Brain tissues from } 5 \text { AD patients and } \\
3 \text { controls, 5XFAD mice }\end{array}$ & $\begin{array}{l}\text { Primary } \\
\text { hippocampal } \\
\text { neuron cells }\end{array}$ & - & - & $\begin{array}{l}\text { Its overexpression alleviated cognitive dysfunction and memory } \\
\text { loss also restored synaptic activity. }\end{array}$ & Lee et al., 2016 \\
\hline miR-193b & $\begin{array}{l}\text { Plasma and CSF samples from AD } \\
\text { patients, MCl patients and control } \\
\text { subjects, APP/PS1 double-transgenic }\end{array}$ & SH-SY5Y, HEK293 & APP & - & $\begin{array}{l}\text { Its upregulation downregulated APP expression so it can be } \\
\text { implicated in AD pathogenesis. }\end{array}$ & Liu et al., 2014a \\
\hline miR-153 & APPswe/PS $\Delta$ E9 mice & $\begin{array}{l}\text { SH-SY5Y, } \\
\text { HEK-293T, M17 }\end{array}$ & APP, APLP2 & - & $\begin{array}{l}\text { Its overexpression downregulated expression APP and APLP2 so } \\
\text { can be an important factor in the pathogenesis of AD. }\end{array}$ & Liang et al., 2012 \\
\hline miR-153 & $\begin{array}{l}\text { Brain tissues from } 15 \text { AD patients and } \\
5 \text { normal controls }\end{array}$ & $\begin{array}{l}\text { HeLa, primary } \\
\text { human fetal brain } \\
\text { cultures }\end{array}$ & APP & - & $\begin{array}{l}\text { Can be implicated in AD pathogenesis through targeting APP and } \\
\text { reducing APP expression }\end{array}$ & Long et al., 2012 \\
\hline miR-16 & $\begin{array}{l}\text { SAMP8 mice, SAMR1 mice, and } \\
\text { BALb/c mice }\end{array}$ & $\begin{array}{l}\text { Neuroblastoma2a } \\
\text { and NIH3T3 }\end{array}$ & APP & - & $\begin{array}{l}\text { Its upregulation downregulated the expression of APP and } \\
\text { consequently prevented APP accumulation. }\end{array}$ & Liu et al., 2012 \\
\hline miR-339-5p & $\begin{array}{l}\text { Frozen brain tissues from } 20 \mathrm{AD} \\
\text { patients and } 5 \text { controls }\end{array}$ & $\begin{array}{l}\text { HeLa, U373MG, } \\
\text { human primary } \\
\text { brain cultures }\end{array}$ & BACE1 & - & Can contribute to AD pathogenesis through targeting BACE1 & Long et al., 2014 \\
\hline
\end{tabular}




\begin{tabular}{|c|c|c|c|c|c|c|}
\hline 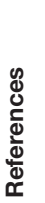 & 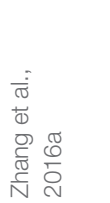 & 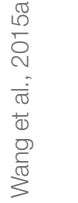 & 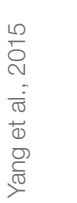 & 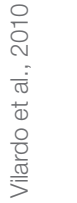 & 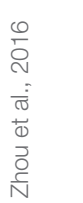 & 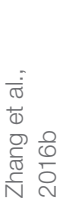 \\
\hline 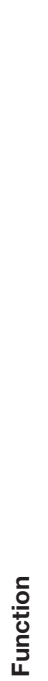 & 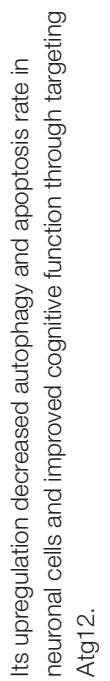 & 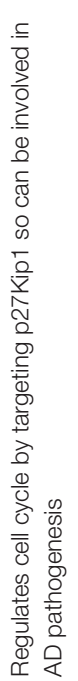 & 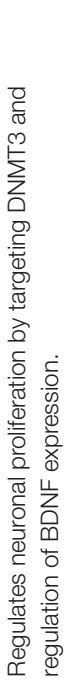 & 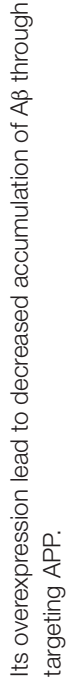 & 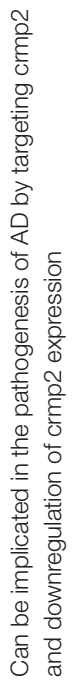 & 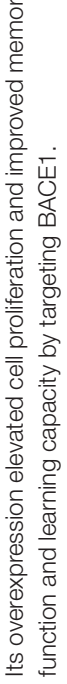 \\
\hline
\end{tabular}

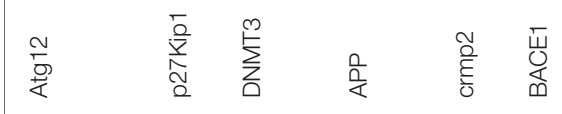

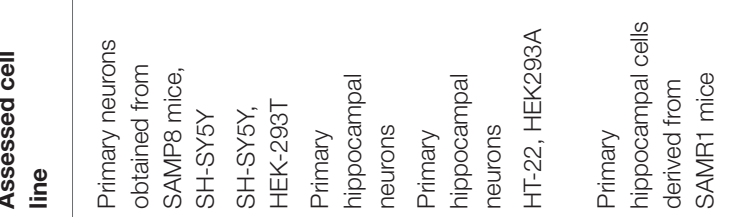

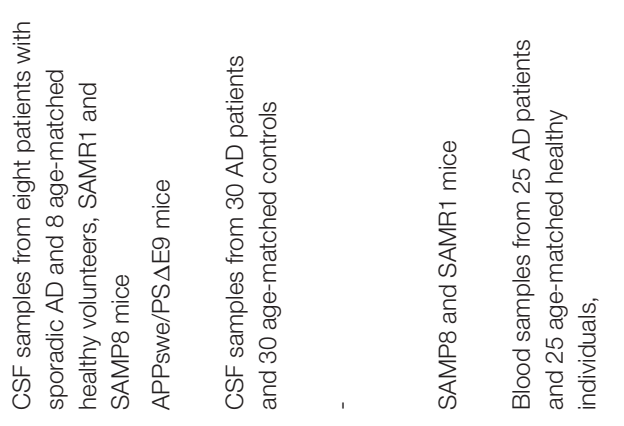

pathogenesis of this condition via targeting Lrp2 and inhibiting the Akt signaling pathway, modulating ROCK1 expression and decreasing Tau phosphorylation, and influencing inflammatory responses via modulation of IRAK-1 (Cui et al., 2010; Wang et al., 2016). Insulin and liver $X$ receptor (LXR) activators have been shown to increase the miR-7-1 levels. Expression of this miRNA has changed within the brains of diet-induced obese animals as well as $\mathrm{AD}$ patients, which is in parallel with the downregulation of its target genes IRS-2 and IDE. Upregulation of miR-7 has enhanced extracellular $A \beta$ levels in neurons and interfered with the eradication of $A \beta$ by microglia. Collectively, insulin can act via the HNRNPK-miR-7 cascade to post-transcriptionally affect metabolic pathways in AD (Fernández-de Frutos et al., 2019). Table 2 lists upregulated miRNAs in AD.

Figure 1 demonstrates the function of a number of miRNAs in the pathogenesis of $\mathrm{AD}$.

\section{PROGNOSTIC AND DIAGNOSTIC ROLE OF MIRNAS IN AD}

The prognostic role of miRNAs in $\mathrm{AD}$ has been assessed in a single study. Xie et al. have evaluated serum levels of miR206, miR-132, BDNF, and SIRT1 in a cohort of patients with amnestic mild cognitive impairment at baseline and after 5year follow-up. Their results have shown higher levels of miR206 in patients who converted to $\mathrm{AD}$ both at the baseline and after 5-year follow-up. However, miR-132 levels have been statistically similar between the conversion and non-conversion groups at both time points. Based on the Kaplan-Meier analysis, $\mathrm{AD}$ conversion has been correlated with over-expression of miR-206. In addition, multivariate Cox regression analysis has shown the suitability of serum miR-206 and its target BDNF as indicators of $\mathrm{AD}$ conversion (Xie et al., 2017). The diagnostic role of several miRNAs has been appraised in AD. For instance, downregulation of miR-433 and miR-133b in serum samples could precisely differentiate between $\mathrm{AD}$ subjects and normal persons (Yang et al., 2019b; Wang and Zhang, 2020). Moreover, the expression profile of the former miRNA in the cerebrospinal fluid (CSF) has appropriate diagnostic power for distinguishing AD patients (Wang and Zhang, 2020). The most astonishing results have been obtained for miR-34c. Expression of miR-34c has been increased in both cellular and plasma constituents of blood specimens of $\mathrm{AD}$ patients. The area under the receiver operating characteristic curve has been estimated to be 0.99 . Moreover, expression of miR-34c has been inversely correlated with mental performance, as described by the mini-mental state examination. miR-34c has also been shown to affect the expression of numerous genes being involved in neuron survival and oxidative processes (Bhatnagar et al., 2014). Expression levels of miR-132 and miR-212 in neural-derived extracellular vesicles have been demonstrated to differentiate patients with $\mathrm{AD}$ from healthy subjects, yet their aptitude in identifying both $\mathrm{AD}$ and mild cognitive impairment as different from a healthy status has not been suitable (Cha et al., 2019). Table 3 summarizes the outlines of various studies that have reported on the diagnostic value of miRNAs in $\mathrm{AD}$. 
TABLE 2 | Upregulated miRNAs in AD subject, animal models of AD or related cell lines and their functions in progression of AD.

\begin{tabular}{|c|c|c|c|c|c|c|}
\hline microRNA & Samples & $\begin{array}{l}\text { Assessed cell } \\
\text { line }\end{array}$ & $\begin{array}{l}\text { Gene/protein } \\
\text { interaction }\end{array}$ & $\begin{array}{l}\text { Signaling } \\
\text { pathway }\end{array}$ & Function & References \\
\hline miR-132 & $\begin{array}{l}\text { Frozen human postmortem brain specimens } \\
\text { from } 10 \text { patients with mild cognitive } \\
\text { impairment, } 10 \text { patients with } A D \text {, and } 10 \\
\text { controls }\end{array}$ & $\begin{array}{l}\text { Human cortical } \\
\text { neuron culture }\end{array}$ & GTDC-1 & - & $\begin{array}{l}\text { Enhances neuronal apoptosis and Tau phosphorylation by } \\
\text { targeting GTDC-1 }\end{array}$ & $\begin{array}{l}\text { Liu and Zhang, } \\
2019\end{array}$ \\
\hline miR-30b & $\begin{array}{l}\text { Human hippocampal tissues, C57BL/6J mice, } \\
\text { and 5XFAD APP transgenic mice }\end{array}$ & $\begin{array}{l}\text { NG108-15, HEK } \\
\text { 293/293T }\end{array}$ & $\begin{array}{l}\text { ephB2, sirt1, } \\
\text { GluA2 }\end{array}$ & $\begin{array}{l}\text { NF-kB signaling } \\
\text { pathway }\end{array}$ & $\begin{array}{l}\text { Disrupts cognitive and synaptic functions and its knockdown } \\
\text { reverses this effect by targeting ephB2, sirt1, and GluA2 }\end{array}$ & Song et al., 2019 \\
\hline $\mathrm{miR}-128$ & $\begin{array}{l}\text { APP/PSA/Tau triple transgenic mice and } \\
\text { C57BL/6 mice }\end{array}$ & N2a cells & PPAR $\gamma$ & - & $\begin{array}{l}\text { Its knockout suppressed AD development, } A \beta \text { production, and } \\
\text { inflammatory reactions by targeting PPAR } \gamma \text {. }\end{array}$ & Liu et al., 2019 \\
\hline $\operatorname{miR}-128$ & $\begin{array}{l}\text { Plasma samples from } 20 \text { patients with } A D \text { and } \\
\text { age and education-matched normal subjects }\end{array}$ & MCN, Neuro2a & PPAR- $\gamma$ & - & $\begin{array}{l}\text { Its inhibition abated neurotoxicity of A } \beta \text { through regulation of } \\
\text { PPAR- } \gamma \text { and deactivated NF-KB. }\end{array}$ & Geng et al., 2018 \\
\hline $\operatorname{miR}-7$ & $\begin{array}{l}\text { Postmortem human brains from AD patients } \\
\text { and individuals without severe neurological and } \\
\text { psychological disorders male C57BL/6 mice }\end{array}$ & N2a cell, BV-2 & $\begin{array}{l}\text { INSR, IRS-2, } \\
\text { IDE }\end{array}$ & Insulin signaling & $\begin{array}{l}\text { Enhances extracellular } A \beta \text { and suppresses its clearance by } \\
\text { regulating Insulin signaling through targeting INSR, IRS-2, and IDE }\end{array}$ & $\begin{array}{l}\text { Fernández-de } \\
\text { Frutos et al., } 2019\end{array}$ \\
\hline miR-592 & $\begin{array}{l}54 \text { Sprague-Dawley (SD) male rats established } \\
\text { as an AD model }\end{array}$ & Astrocyte culture & KIAA0319 & $\begin{array}{l}\text { Keap1/Nrf2/ARE } \\
\text { signaling pathway }\end{array}$ & $\begin{array}{l}\text { Its downregulation attenuated oxidative stress and enhanced cell } \\
\text { survival through upregulation of KIAA0319. }\end{array}$ & Huang et al., 2020 \\
\hline$m i R-425-5 p$ & Postmortem brain tissue samples from & HEK293/tau & HSPB8 & - & $\begin{array}{l}\text { Elevates apoptosis and tau phosphorylation through } \\
\text { downregulation of HSPB8 }\end{array}$ & Yuan et al., 2020 \\
\hline $\begin{array}{l}\text { miR-425-5p } \\
\text { miR-339-5p }\end{array}$ & $\begin{array}{l}\text { Blood samples (for PBMC) from } 45 \text { AD patients } \\
\text { and } 41 \text { age- and gender-matched healthy } \\
\text { controls }\end{array}$ & N2a/APPswe & BACE1 & - & $\begin{array}{l}\text { Can be implicated in AD pathogenesis through modulating } \\
\text { expression of BACE1 }\end{array}$ & Ren et al., 2016 \\
\hline $\mathrm{miR}-25$ & 30 male Kunming mice & $\begin{array}{l}\text { Hippocampal } \\
\text { neuronal cells }\end{array}$ & KLF2 & $\begin{array}{l}\text { Nrf2 signaling } \\
\text { pathway }\end{array}$ & $\begin{array}{l}\text { Represses proliferation of hippocampal neuron cells and induced } \\
\text { apoptosis in these cells by targeting KLF2 }\end{array}$ & Duan and Si, 2019 \\
\hline miR-138 & - & SH-SY5Y & DEK & - & $\begin{array}{l}\text { Increases apoptosis rate in SH-SY5Y cells by targeting DEK and } \\
\text { downregulation of its expression }\end{array}$ & Miao et al., 2020 \\
\hline miR-138q & - & $\begin{array}{l}\text { N2a/APP, } \\
\text { HEK293/tau }\end{array}$ & RARA & - & $\begin{array}{l}\text { Can be implicated in the pathogenesis of } A D \text { through the } \\
\text { promotion of tau phosphorylation by targeting RARA }\end{array}$ & Wang et al., 2015b \\
\hline$m i R-149-5 p$ & $\begin{array}{l}\text { Plasma samples from } 30 \mathrm{AD} \text { patients and } 30 \\
\text { healthy controls }\end{array}$ & 293/APPsw & KAT8 & - & $\begin{array}{l}\text { Can be implicated in AD pathology by targeting KAT8 to negatively } \\
\text { regulate H } 4 \text { K } 16 \mathrm{ac}\end{array}$ & Zhou et al., 2020 \\
\hline$m i R-125 b$ & $\begin{array}{l}\text { Cerebral tissues from nine AD patients, eight } \\
\text { patients with } \mathrm{MCl} \text {, and } 10 \text { normal individuals }\end{array}$ & $\begin{array}{l}\text { Neuronal cells } \\
\text { obtained from } \\
\text { human fatal } \\
\text { cortical tissues }\end{array}$ & FOXQ1 & - & $\begin{array}{l}\text { Promotes phosphorylation of Tau and apoptosis of neuronal cells } \\
\text { by targeting FOXQ1 }\end{array}$ & Ma et al., 2017 \\
\hline miR-125b & $\begin{array}{l}\text { CSF samples from } 24 \mathrm{AD} \text { patients and } 24 \\
\text { healthy controls }\end{array}$ & $\begin{array}{l}\text { Neuro2a } \\
\text { APPSwe/ } \triangle 9\end{array}$ & - & - & $\begin{array}{l}\text { Promotes cellular apoptosis, oxidative stress, and expression of } \\
\text { inflammatory factors and suppressed cell proliferation by } \\
\text { regulating SphK1 }\end{array}$ & Jin et al., 2018 \\
\hline $\mathrm{miR}-125 \mathrm{~b}$ & $\begin{array}{l}\text { Brain tissue specimens } 10 \mathrm{AD} \text { patients and } 5 \\
\text { healthy controls, C57BL/6 wild-type mice }\end{array}$ & $\begin{array}{l}\text { Primary } \\
\text { hippocampal and } \\
\text { cortical neuron } \\
\text { obtained from } \\
\text { embryonic day } 19 \\
\text { rat }\end{array}$ & $\begin{array}{l}\text { BCl-W, } \\
\text { DUSP6, } \\
\text { PPP1CA }\end{array}$ & MAPK signaling & $\begin{array}{l}\text { Its high expression resulted in increased tau phosphorylation } \\
\text { through targeting Bcl-W, DUSP6 and PPP1CA. also its } \\
\text { overexpression led to perished associative learning in mice. }\end{array}$ & $\begin{array}{l}\text { Banzhaf- } \\
\text { Strathmann et al., } \\
2014\end{array}$ \\
\hline
\end{tabular}


TABLE 2 | Continued

\begin{tabular}{|c|c|c|c|c|c|c|}
\hline microRNA & Samples & $\begin{array}{l}\text { Assessed cell } \\
\text { line }\end{array}$ & $\begin{array}{l}\text { Gene/protein } \\
\text { interaction }\end{array}$ & $\begin{array}{l}\text { Signaling } \\
\text { pathway }\end{array}$ & Function & References \\
\hline $\begin{array}{l}\text { miR-200b } \\
\text { miR-200c }\end{array}$ & Wild-type C57BL/6J mice and Tg2576 mice & PMNCs, SH-SY5Y & - & - & $\begin{array}{l}\text { Transfection with miR-200b/miR-200c alleviated memory } \\
\text { impairment and improved spatial learning through regulation of } \\
\text { S6K1-mediated insulin signaling. }\end{array}$ & Higaki et al., 2018 \\
\hline miR-200c & $\begin{array}{l}\text { Plasma samples from } 14 \mathrm{AD} \text { patients and } 13 \\
\text { normal controls, APPswe/PS1 } \triangle \mathrm{ES} \\
\text { double-transgenic mice }\end{array}$ & PC12 & PTEN & - & $\begin{array}{l}\text { Its overexpression improved neuronal survival and neurite } \\
\text { outgrowth by targeting PTEN. }\end{array}$ & Wu et al., 2016 \\
\hline miR-10a & 50 male Sprague-Dawley (SD) rats & - & BDNF & $\begin{array}{l}\text { BDNF-TrkB } \\
\text { signaling pathway }\end{array}$ & $\begin{array}{l}\text { Promotes apoptosis and cell growth arrest by targeting BDNF and } \\
\text { inhibition of BDNF-TrkB signaling pathway }\end{array}$ & Wu et al., 2018b \\
\hline miR-1908 & $\begin{array}{l}\text { Blood samples from } 20 \mathrm{AD} \text { patients and } 20 \\
\text { age-matched control individuals }\end{array}$ & THP-1, U87 & ApoE & - & $\begin{array}{l}\text { Disrupts clearance of } A \beta \text { by } A p o E \text { through downregulation of its } \\
\text { expression }\end{array}$ & Wang et al., 2018 \\
\hline miR-139 & SAMR1 and SAMP8 mice & $\begin{array}{l}\text { Primary } \\
\text { hippocampal cell }\end{array}$ & CB2 & - & $\begin{array}{l}\text { Its overexpression improved memory function and learning ability } \\
\text { by targeting CB2. }\end{array}$ & Tang et al., 2017 \\
\hline miR-146a & - & SH-SY5Y & Lrp2 & $\begin{array}{l}\text { Akt signaling } \\
\text { pathway }\end{array}$ & $\begin{array}{l}\text { Raised the rate of cellular apoptosis through targeting Lrp2 and } \\
\text { inhibition of Akt signaling pathway }\end{array}$ & Wang et al., 2016 \\
\hline miR-146a & Brain tissues from $17 \mathrm{AD}$ patients, 5xFAD mice & SH-SY5Y & ROCK1 & $\begin{array}{l}\text { ROCK1/PTEN } \\
\text { pathway }\end{array}$ & $\begin{array}{l}\text { Its inhibition decreased phosphorylation of tau proteins and } \\
\text { improved memory function by modulating ROCK1 expression. }\end{array}$ & Wang et al., 2016 \\
\hline miR-146a & $\begin{array}{l}\text { Brain tissues from } 36 \mathrm{AD} \text { patients and } 30 \\
\text { control subjects }\end{array}$ & $\begin{array}{l}\text { Primary human } \\
\text { astroglial (HAG) } \\
\text { cells, primary HNG }\end{array}$ & IRAK-1 & - & $\begin{array}{l}\text { Targets IRAK-1 and downregulated its expression so caused a } \\
\text { sustained inflammatory response }\end{array}$ & Cui et al., 2010 \\
\hline miR-33 & APPsw/PSEN1 $\Delta 9$ (APP/PS1) transgenic mice & $\begin{array}{l}\text { N2a, N2a-APPsw, } \\
\text { H4-APPsw }\end{array}$ & ABCA1 & - & $\begin{array}{l}\text { Downregulates expression of } A B C A 1 \text { and consequently impaired } \\
A \beta \text { clearance }\end{array}$ & Kim et al., 2015 \\
\hline miR-34c & C57 mice & $\begin{array}{l}\text { Primary } \\
\text { hippocampal } \\
\text { neurons, N2a }\end{array}$ & VAMP2 & - & $\begin{array}{l}\text { Its downregulation alleviated learning and memory dysfunction } \\
\text { and synaptic impairment through targeting VAMP2. }\end{array}$ & Hu et al., 2015 \\
\hline miR-26b & APP/PS1 double-transgenic mice & N2a, HEK293 & IGF-1 & - & $\begin{array}{l}\text { Augments production of A } \beta \text { by targeting IGF-1 and its inhibition } \\
\text { reversed these effects }\end{array}$ & Liu et al., 2016b \\
\hline miR-98 & APP/PS1 mice & HEK293, N2a & IGF-1 & - & $\begin{array}{l}\text { Its inhibition suppressed } A \beta \text { generation and tau phosphorylation } \\
\text { by regulating the expression of IGF-1. }\end{array}$ & Hu et al., 2013 \\
\hline miR-206 & $\begin{array}{l}\text { Blood samples from } 30 \mathrm{AD} \text { patients and } 30 \\
\text { healthy controls }\end{array}$ & BV-2 & IGF-1 & - & $\begin{array}{l}\text { Elevates inflammatory responses induced by LPS and promoted } \\
\text { the release of A } \beta \text { from microglia cell through targeting IGF-1 }\end{array}$ & Xing et al., 2016 \\
\hline miR-574 & $\begin{array}{l}\text { APP/PS1 double transgenic mice and wild type } \\
\text { mice }\end{array}$ & $\begin{array}{l}\text { Primary } \\
\text { hippocampal } \\
\text { neurons obtained } \\
\text { from mice }\end{array}$ & Nrn1 & - & $\begin{array}{l}\text { Is involved in the regulation of synaptic activity and cognitive } \\
\text { function through targeting Nrn1 }\end{array}$ & Li et al., 2015 \\
\hline miR-26b & $\begin{array}{l}\text { Postmortem brain tissues from } 10 \text { patients with } \\
\mathrm{MCl}, 10 \text { patients with } \mathrm{AD} \text {, and eight controls }\end{array}$ & $\begin{array}{l}\text { Primary cortical } \\
\text { neurons obtained } \\
\text { from Sprague } \\
\text { Dawley rat }\end{array}$ & $\mathrm{Rb} 1$ & - & $\begin{array}{l}\text { Promotes tau phosphorylation and cell cycle entry and } \\
\text { consequently lead apoptosis by targeting Rb1 }\end{array}$ & $\begin{array}{l}\text { Absalon et al., } \\
2013\end{array}$ \\
\hline miR-922 & - & $\begin{array}{l}\text { SH-SY5Y, } \\
\text { HEK-293T }\end{array}$ & UCHL1 & - & $\begin{array}{l}\text { Enhances phosphorylation of tau proteins by targeting } U \mathrm{CHL} 1 \text { so } \\
\text { contributed to AD pathogenesis }\end{array}$ & Zhao et al., 2014 \\
\hline miR-485-3p & $\begin{array}{l}\text { Serum samples from } 89 \text { AD patients and } 62 \\
\text { healthy controls }\end{array}$ & SH-SY5Y, BV2 & АКТЗ & - & $\begin{array}{l}\text { Its knockdown promoted cell proliferation, inhibited apoptosis and } \\
\text { neuroinflammation partly by targeting AKT3. Its expression has } \\
\text { been associated with MMSE score, inflammatory response. }\end{array}$ & Yu et al., 2020 \\
\hline
\end{tabular}




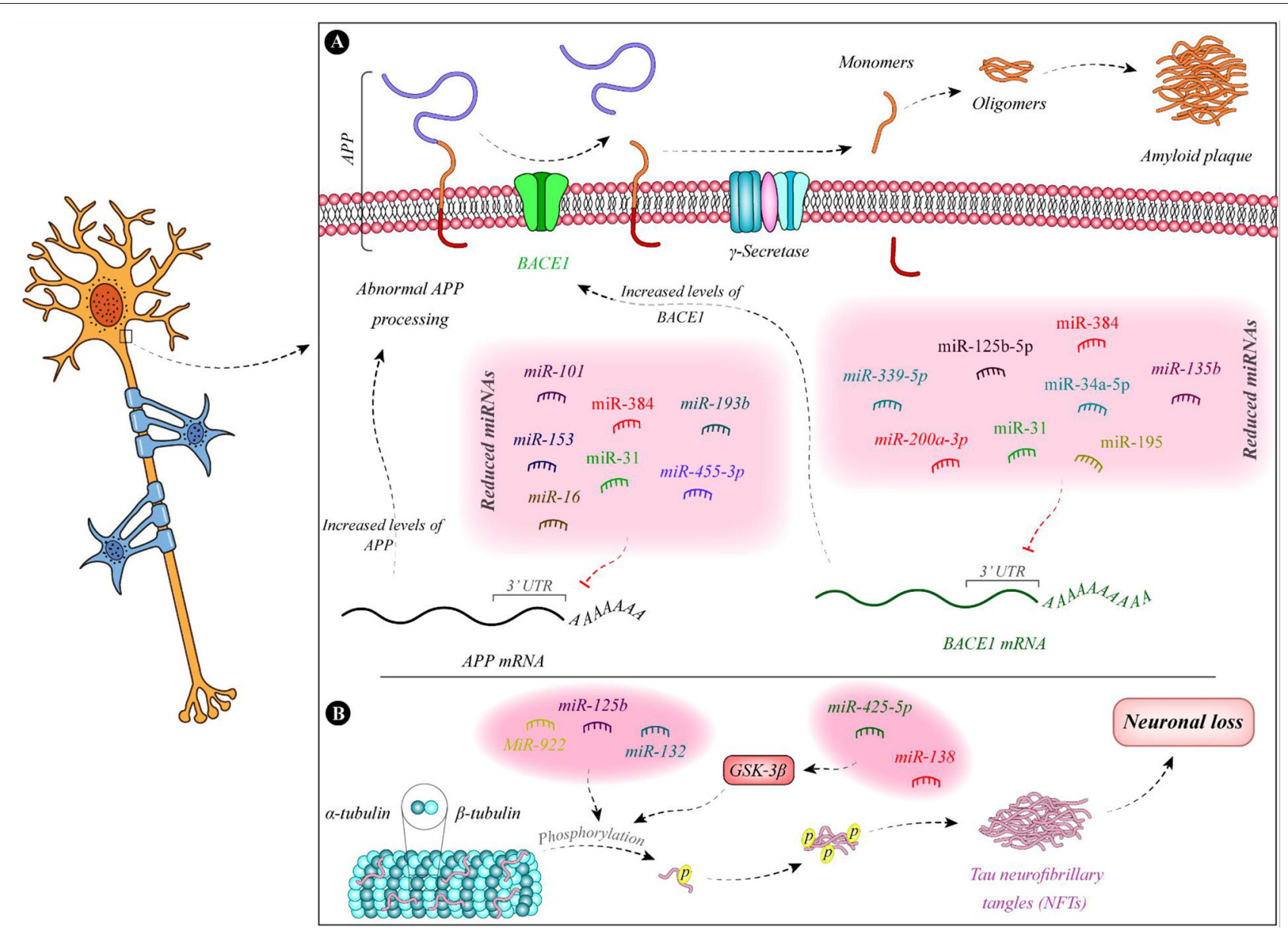

FIGURE 1 | Summary of the function of miRNAs in the pathogenesis of AD. (A) Expressions of miR-135b (Zhang et al., 2016b), miR-195 (Zhu et al., 2012), miR-34a-5p (Liang et al., 2020), miR-384 (Liu et al., 2014b), miR-125b-5p (Liang et al., 2020), miR-31 (Barros-Viegas et al., 2020), miR-200a-3p (Pan et al., 2019), and miR-339-5p (Long et al., 2014) are decreased in patients with Alzheimer's disease. These miRNAs bind with the 3' UTR of BACE1 and decrease its expression. Therefore, the downregulation of these miRNAs leads to the upregulation of BACE1. In addition, expression levels of some APP-binding miRNAs namely miR-101 (Vilardo et al., 2010), miR-153 (Liang et al., 2012), miR-16 (Liu et al., 2012), miR-384 (Liu et al., 2014b), miR-31 (Barros-Viegas et al., 2020), miR-193b (Liu et al., 2014a), and miR-455-3p (Kumar et al., 2019) is decreased in patients with Alzheimer's disease. (B) Tau phosphorylation leads to defects in microtubules and induction of neurofibrillary tangles which result in neuron death. miR-138 and miR-425-5p are increased in Alzheimer's disease. These miRNAs regulate the expression of GSK-3 $\beta$ and enhance Tau phosphorylation (Wang et al., 2015b; Yuan et al., 2020). In addition, downregulation of miR-132 and upregulation of miR-125b and miR-922 leads to Tau hyperphosphorylation (Zhao et al., 2014; Salta et al., 2016; Ma et al., 2017).

\section{MIRNA POLYMORPHISMS AND RISK OF $A D$}

Boscher et al. have screened a larger cohort of early-onset $\mathrm{AD}$ (EOAD) patients who did not have autosomal dominant mutations for the presence of genetic polymorphisms. They have recognized 86 copy number variants (CNVs) in miRNAcoding genes, 31 of them being only present in EOAD cases. Duplication of the MIR138-2 locus has been one of these CNVs. Based on the role of miR-138 in $\mathrm{A} \beta$ production and tau phosphorylation, this $\mathrm{CNV}$ might be implicated in the risk of EOAD (Boscher et al., 2019). Functionally, miR-138 upregulation enhances $A \beta$ synthesis and tau phosphorylation through modulation of GSK-3 $\beta$ and FERMT2 (Boscher et al., 2019). Other studies have demonstrated the role of rs2910164 of
pri-miR-146a, rs57095329 of miR-146a, and rs2291418 of miR1229 precursor in conferring risk of AD (Table 4). Zhang et al. have scanned the coding region of pri-miR-146a in AD patients. Among the four single nucleotide polymorphisms (SNPs) located in this genomic region, rs2910164 has been identified as a risk locus for $\mathrm{AD}$ as the $\mathrm{C}$ allele of this SNP has enhanced risk of $\mathrm{AD}$. Notably, this variant has been shown to reduce the expression of mature miR-146a-5p, releasing TLR2 from its inhibitory effects. Moreover, cell line studies have shown the impact of the $\mathrm{C}$ allele on upregulation of expression of TNF- $\alpha$ after induction with $\beta$ amyloid. Therefore, this SNP might predispose patients to $\mathrm{AD}$ by disturbing the production of mature miRNA and influencing the activity and expression level of TLR2 (Zhang et al., 2015). Cui et al. have analyzed the genotype and allele frequencies of rs2910464 and rs57095329 of miR-146a and have reported that 
TABLE 3 | Diagnostic role of miRNAs in AD.

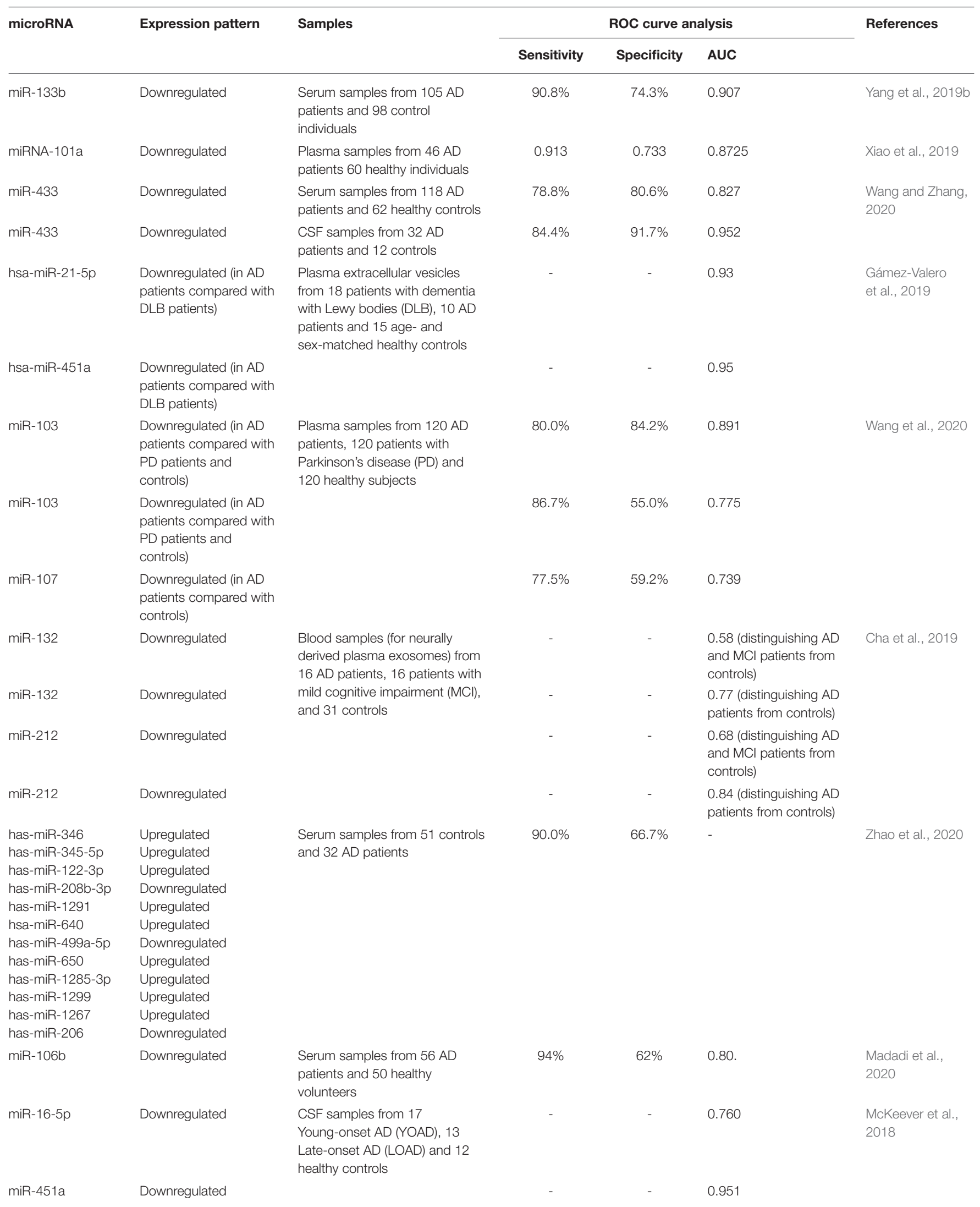


TABLE 3 | Continued

\begin{tabular}{|c|c|c|c|c|c|c|}
\hline microRNA & Expression pattern & Samples & \multicolumn{3}{|c|}{ ROC curve analysis } & References \\
\hline miR-125b-5p & Upregulated & & - & - & 0.723 & \\
\hline miR-451a & Downregulated & & - & - & 0.847 & \\
\hline miR-605-5p & Downregulated & & - & - & 0.765 & \\
\hline miR-501-3p & Downregulated & $\begin{array}{l}\text { Serum samples from } 36 \text { patients } \\
\text { with } A D \text { and } 22 \text { age-matched } \\
\text { control volunteers }\end{array}$ & $53 \%$ & $100 \%$ & 0.82 & Hara et al., 2017 \\
\hline $\begin{array}{l}\text { hsa-miR-26a-5p } \\
\text { hsa-miR-181c-3p } \\
\text { hsa-miR-126-5p } \\
\text { hsa-miR-22-3p } \\
\text { hsa-miR-148b-5p } \\
\text { hsa-miR-106b-3p } \\
\text { hsa-miR-6119-5p } \\
\text { hsa-miR-1246 } \\
\text { hsa-miR-660-5p }\end{array}$ & $\begin{array}{l}\text { Downregulated } \\
\text { Downregulated } \\
\text { Downregulated } \\
\text { Downregulated } \\
\text { Downregulated } \\
\text { Upregulated } \\
\text { Upregulated } \\
\text { Upregulated } \\
\text { Upregulated }\end{array}$ & $\begin{array}{l}\text { Serum samples } 121 \text { patients } \\
\text { with } A D \text { and } 86 \text { healthy controls }\end{array}$ & - & - & 0.987 & Guo et al., 2017 \\
\hline hsa-miR-106a-5p & Downregulated & $\begin{array}{l}\text { Blood samples from } 172 \mathrm{AD} \\
\text { patients and } 109 \text { healthy controls }\end{array}$ & $68 \%$ & $93 \%$ & - & Yilmaz et al., 2016 \\
\hline $\begin{array}{l}\text { miR-31 } \\
\text { miR-93 } \\
\text { miR-143 } \\
\text { miR-146a }\end{array}$ & $\begin{array}{l}\text { Downregulated } \\
\text { Downregulated } \\
\text { Downregulated } \\
\text { Downregulated }\end{array}$ & $\begin{array}{l}\text { Serum samples } 79 \text { AD patients } \\
\text { and } 75 \text { controls }\end{array}$ & - & - & 0.709 & Li et al., 2015 \\
\hline miR-342-3p & Downregulated & $\begin{array}{l}\text { Serum samples from } 208 \\
\text { patients with } A D \text { and } 205 \text { age- } \\
\text { and sex-matched healthy } \\
\text { volunteers }\end{array}$ & $81.5 \%$ & $70.1 \%$ & - & Tan et al., 2014 \\
\hline miR-125a-5p & Upregulated & $\begin{array}{l}\text { CSF samples from } 48 \text { patients } \\
\text { with behavioral variant of } \\
\text { frontotemporal dementia } \\
\text { (bvFTD), } 48 \text { patients with AD and } \\
44 \text { healthy controls }\end{array}$ & $74 \%$ & $82 \%$ & 0.75 & Denk et al., 2018 \\
\hline miR-29b-3p & Upregulated & & $93 \%$ & - & 0.83 & \\
\hline miR-26b-5p & Upregulated & & $89 \%$ & $89 \%$ & 0.97 & \\
\hline miR-320a & Downregulated & & $83 \%$ & $90 \%$ & 0.90 & \\
\hline$m i R-483-5 p$ & Upregulated & $\begin{array}{l}\text { Plasma samples from } 20 \mathrm{AD} \\
\text { patients, } 15 \mathrm{MCl}-\mathrm{AD} \text { patients } \\
\text { and } 15 \text { non-demented controls } \\
\text { (CTR) }\end{array}$ & - & - & 0.99 (AD vs. CTR) & $\begin{array}{l}\text { Nagaraj et al., } \\
2017\end{array}$ \\
\hline miR-483-5p & & & - & - & 0.95 (MCl-AD vs. CTR) & \\
\hline miR-502-3p & Upregulated & & - & - & 0.94 (AD vs. CTR) & \\
\hline miR-502-3p & & & - & - & 0.86 (MCl-AD vs. CTR) & \\
\hline miR-485-3p & Upregulated & $\begin{array}{l}\text { Serum samples from } 89 \mathrm{AD} \\
\text { patients and } 62 \text { healthy controls }\end{array}$ & $84.3 \%$ & $96.8 \%$ & 0.933 & Yu et al., 2020 \\
\hline miR-425 & Upregulated & $\begin{array}{l}\text { Blood samples (for PBMC) from } \\
45 \text { AD patients and } 41 \text { age- and } \\
\text { gender-matched healthy controls }\end{array}$ & - & - & 0.868 & Ren et al., 2016 \\
\hline miR-339 & Upregulated & & - & - & 0.761 & \\
\hline miR-206 & $\begin{array}{l}\text { Upregulated (in } \\
\text { aMCl-AD group } \\
\text { compared with } \\
\text { aMCl-aMCl group) }\end{array}$ & $\begin{array}{l}\text { Serum sample from } 458 \\
\text { amnestic mild cognitive } \\
\text { impairment (aMCI) }\end{array}$ & $95.5 \%$ & $77.8 \%$ & 0.95 & Xie et al., 2017 \\
\hline
\end{tabular}


TABLE 3 | Continued

\begin{tabular}{|c|c|c|c|c|c|c|}
\hline microRNA & Expression pattern & Samples & \multicolumn{3}{|c|}{ ROC curve analysis } & References \\
\hline miR-455-3p & Upregulated & $\begin{array}{l}\text { Skin fibroblast cell from } 4 \\
\text { patients with familial } A D, 6 \\
\text { patients with sporadic } A D \text {, and } \\
\text { eight healthy control }\end{array}$ & - & - & 0.861 & \\
\hline miR-455-3p & Upregulated & $\begin{array}{l}\text { Serum samples from } 10 \mathrm{AD} \\
\text { patients, } 20 \mathrm{MCl} \text { patients and } 18 \\
\text { healthy controls }\end{array}$ & - & - & 0.79 & Kumar et al., 2017 \\
\hline miR-455-3p & Upregulated & $\begin{array}{l}\text { Postmortem brain tissues from } \\
16 \text { AD patients and } 5 \text { controls }\end{array}$ & - & - & 0.86 & \\
\hline miR-34c & Upregulated & $\begin{array}{l}\text { Plasma samples from } 110 \mathrm{AD} \\
\text { patients and } 123 \text { control subjects }\end{array}$ & 0.92 & 0.96 & 0.99 & $\begin{array}{l}\text { Bhatnagar et al., } \\
2014\end{array}$ \\
\hline
\end{tabular}

TABLE 4 | miRNA polymorphisms and risk of AD.

\begin{tabular}{|c|c|c|c|c|c|c|}
\hline microRNA & Polymorphism & Samples & Population & Assay method & Function & References \\
\hline$m i R-138$ & $\begin{array}{l}\text { Copy number } \\
\text { variant (CNV) }\end{array}$ & $\begin{array}{l}\text { Whole exome sequencing } \\
\text { data of } 546 \text { unrelated } \\
\text { patients with early-onset } \\
\text { Alzheimer's disease (EOAD) } \\
\text { and } 597 \text { controls subjects }\end{array}$ & French & QMPSF & $\begin{array}{l}\text { Its duplication was observed in EOAD } \\
\text { patients and functional studies } \\
\text { showed that miR-138 upregulation } \\
\text { caused increased production of } A \beta \\
\text { and higher phosphorylation of tau. } \\
\text { So miR-138 gene dosage can be a } \\
\text { potential risk factor for EOAD. }\end{array}$ & $\begin{array}{l}\text { Boscher et al., } \\
2019\end{array}$ \\
\hline miR-146a & $\begin{array}{l}\text { SNP } \\
\text { (rs57095329) }\end{array}$ & $\begin{array}{l}\text { Blood samples from } 292 \mathrm{AD} \\
\text { patients } 300 \text { healthy } \\
\text { volunteers }\end{array}$ & Chinese & $\begin{array}{l}\text { ABI PRISM } \\
\text { SNapShot method }\end{array}$ & $\begin{array}{l}\text { AA genotype of rs } 57095329 \text { was } \\
\text { correlated with an elevated } \\
\text { predisposition to } A D \text { and was } \\
\text { associated with high expression of } \\
\text { miR-146a. }\end{array}$ & Cui et al., 2014 \\
\hline
\end{tabular}

the AA genotype of the former SNP increases susceptibility to $\mathrm{AD}$ and results in cognitive reduction in the affected individuals. Contrary to the previously mentioned study by Zhang et al., the risk genotype has been associated with higher levels of miR-146a in the PBMCs of control subjects and has exerted more robust effects on IL-6 and IL- $1 \beta$ synthesis following stimulation with LPS (Cui et al., 2014). Finally, in a genome-wide association study, Ghanbari et al. have detected an association between rs2291418 in the miR-1229 precursor and risk of AD. The risk allele of this SNP has been shown to increase the expression of miR-1229-3p, thus decreasing the expression of SORL1, an ADassociated gene. In addition, among more than 42,000 variants in miRNA-binding regions, 10 variants in the 3' UTR of nine genes have been associated with this disorder; among them has been rs6857, which enhances the miR-320e-mediated modulation of PVRL2 expression (Ghanbari et al., 2016).

\section{EFFECTS OF HERBAL/CHEMICAL AGENTS ON THE EXPRESSION OF MIRNAS IN THE CONTEXT OF AD}

Osthole, the active component of the fruits of the genus Cnidium moonnieri (L.) Cussion has been shown to affect the AD course via modulation of miRNAs expression. Lin et al. have shown miR-101a-3p as the main affected miRNA by osthole. APP 
has been identified as the target of miR-101a-3p. Osthole has enhanced the learning and memory aptitude in an animal model of $\mathrm{AD}$, and it has inhibited APP levels by promoting the expression of miR-101a-3p (Lin et al., 2019). Other studies have verified the effects of Osthole on the expression of miR9 (Li et al., 2016, 2017). Functionally, osthole enhances the viability of neurons, decreases apoptosis of these cells, and reverses the decline of synaptic proteins in APP-expressing cells by affecting miR-9 expression and consequently decreasing CAMKK2 and p-AMPK $\alpha$ levels (Li et al., 2016). Additionally, osthole has pro-survival effects in APP-expressing neural stem cells through suppression of the Notch pathway (Li et al., 2017). Moreover, Berberine has been shown to enhance proliferation and attenuate neuron apoptosis via regulation of miR-188/NOS1 molecular cascade (Chen et al., 2020b). Treatment of $A \beta$ treated murine microglia and neuroblastoma cells with this substance or upregulation of miR-188 in these cells has accelerated cell proliferation and suppressed caspase- 3 activity and apoptosis (Chen et al., 2020b). Finally, exmedetomidine has been demonstrated to accomplish neuroprotective effects and enhance cognitive function in an animal model of AD by modulating the miR-129/YAP1/JAG1 cascade (Sun et al., 2020). Table 5 shows the effects of different AD-modifying compounds on the expression of miRNAs.

\section{DISCUSSION}

Numerous studies have demonstrated abnormal expression of miRNAs in AD subjects or cell/animal models of AD. However, each miRNA has been the subject of expression and functional assays in few independent studies. miR-146 has been among the miRNAs most assessed in the context of $\mathrm{AD}$, as its expression levels, functions, and polymorphisms have been assessed in association with $\mathrm{AD}$. miR-9 is another $\mathrm{AD}$-associated miRNA whose expression has been altered following treatment of APPexpressing cells with anti-AD substances. In some cases, altered expression of a certain miRNA is regarded as a part of a self-protective process. For instance, the reduction of miR-409$5 p$ expression in the early stages of $A D$ might be associated with lower A $\beta$-induced synaptic injury (Guo et al., 2019). Similarly, upregulation of miR-200b and $\mathrm{miR}-200 \mathrm{c}$ has protective effects against AD-associated neurotoxicity (Higaki et al., 2018). However, in most cases, an aberrant miRNA signature directly participates in the pathogenesis of AD. miRNAs partake in the pathobiology of $\mathrm{AD}$ through various mechanisms, including the regulation of BACE1 activity. miR-200a-3p, miR-195, miR-3385p, miR-34a-5p, miR-125b-5p, miR-132, miR-384, miR-339-5p, miR-135b, miR-425-5p, and miR-339-5p are among the miRNAs whose interaction with BACE1 has been verified in different investigation. Other miRNAs, such as miR-129-5p, miR-22, and miR-206, might affect the inflammatory responses in the course of AD. Moreover, a number of miRNAs, such as miR326, miR-338-5p, miR-124-3p, miR-34a, miR-326, and miR-98, modulate apoptotic pathways in neurons, thereby affecting the $\mathrm{AD}$ course via this route. Tau phosphorylation can be modulated by some miRNAs, namely, miR-200a-3p, miR-326, miR-124-3p, miR-146a, miR-425-5p, and miR-132. Expression of miR-132 has been assessed by several investigations with most of them

\begin{tabular}{|c|c|c|c|c|c|c|}
\hline miR-9 & Osthole & $\begin{array}{l}\text { SH-SY5Y, primary cortical } \\
\text { neurons obtained from } \\
\text { C57BL/6 mice }\end{array}$ & - & - & $\begin{array}{l}\text { Osthole improved cell survival and } \\
\text { suppressed apoptosis through } \\
\text { upregulation of miR-9 expression. }\end{array}$ & Li et al., 2016 \\
\hline miR-188 & Berberine & $\mathrm{BV} 2, \mathrm{~N} 2 \mathrm{a}$ & - & NOS1 & $\begin{array}{l}\text { Berberine enhanced proliferation and } \\
\text { inhibited apoptosis partly through } \\
\text { regulation of the miR-188/NOS1 axis }\end{array}$ & Chen et al., 2020b \\
\hline miR-129 & Dexmedetomidine & $\begin{array}{l}\text { Primary hippocampal } \\
\text { neurons }\end{array}$ & $\begin{array}{l}\text { Male NIH Swiss } \\
\text { mice }\end{array}$ & YAP1 & $\begin{array}{l}\text { miR-129 was upregulated by } \\
\text { Dexmedetomidine and its } \\
\text { upregulation led to decreased } \\
\text { apoptosis rate and alleviated } \\
\text { cognitive decline through targeting } \\
\text { YAP1 and prevention of YAP1 } \\
\text { interaction with JAG1 }\end{array}$ & Sun et al., 2020 \\
\hline
\end{tabular}


reporting its downregulation in $\mathrm{AD}$ (Wong et al., 2013; El Fatimy et al., 2018; Cha et al., 2019; Deng et al., 2020). Yet, Liu et al. have reported over-expression of miR-132 in patients with mild cognitive impairment and $\mathrm{AD}$ vs. normal individuals (Liu and Zhang, 2019).

Abnormal levels of miRNAs in serum or CSF samples have been shown to distinguish $\mathrm{AD}$ subjects from normal subjects, indicating their suitability as disease biomarkers. However, these studies have not been validated in independent cohorts. miR103, miR-126, miR-93, miR-29, miR-424, and miR-181 are among $\mathrm{AD}$-associated miRNAs with biomarker potential whose application as disease biomarkers has been validated in other disorders (So et al., 2020).

Animal studies have shown promising results regarding the impact of miRNA modifications on the course of AD. However, based on the unavailability of brain tissue for therapeutic interventions in human subjects, identification of appropriate transport mechanisms for delivery of anta-/ago-miRs to this tissue is an important issue.

The anti-AD effects of Osthole, Tiaoxin Recipe, Berberine, and Dexmedetomidine have been shown to be exerted through

\section{REFERENCES}

Absalon, S., Kochanek, D. M., Raghavan, V., and Krichevsky, A. M. (2013). MiR-26b, upregulated in Alzheimer's disease, activates cell cycle entry, tauphosphorylation, and apoptosis in postmitotic neurons. J. Neurosci. 33, 14645-14659. doi: 10.1523/JNEUROSCI.1327-13.2013

Akhter, R., Shao, Y., Shaw, M., Formica, S., Khrestian, M., Leverenz, J. B., et al. (2018). Regulation of ADAM10 by miR-140-5p and potential relevance for Alzheimer's disease. Neurobiol. Aging. 63, 110-119. doi: 10.1016/j.neurobiolaging.2017.11.007

Ballard, C., Gauthier, S., Corbett, A., Brayne, C., Aarsland, D., and Jones, E. (2011). Alzheimer's disease. Lancet 377, 1019-1031. doi: 10.1016/S0140-6736(10)61349-9

Banzhaf-Strathmann, J., Benito, E., May, S., Arzberger, T., Tahirovic, S., Kretzschmar, H., et al. (2014). Micro RNA-125b induces tau hyperphosphorylation and cognitive deficits in Alzheimer's disease. EMBO J. 33, 1667-1680. doi: 10.15252/embj.201387576

Barros-Viegas, A. T., Carmona, V., Ferreiro, E., Guedes, J., Cardoso, A. M., Cunha, P., et al. (2020). MiRNA-31 improves cognition and abolishes amyloid- $\beta$ pathology by targeting APP and BACE1 in an animal model of Alzheimer's disease. Mol. Therapy Nucl. Acids 19, 1219-1236. doi: 10.1016/j.omtn.2020.01.010

Bhatnagar, S., Chertkow, H., Schipper, H. M., Shetty, V., Yuan, Z., Jones, T., et al. (2014). Increased microRNA-34c abundance in Alzheimer's disease circulating blood plasma. Front. Mol. Neurosci. 7:2. doi: 10.3389/fnmol.2014.00002

Boscher, E., Husson, T., Quenez, O., Laquerrière, A., Marguet, F., Cassinari, K., et al. (2019). Copy number variants in miR-138 as a potential risk factor for early-onset Alzheimer's disease. J. Alzheimer's Dis. 68, 1243-1255. doi: 10.3233/JAD-180940

Cao, J., Huang, M., Guo, L., Zhu, L., Hou, J., Zhang, L., et al. (2020). MicroRNA-195 rescues ApoE4-induced cognitive deficits and lysosomal defects in Alzheimer's disease pathogenesis. Mol. Psychiatry. 2020, 1-15. doi: 10.1038/s41380-020-0824-3

Cha, D. J., Mengel, D., Mustapic, M., Liu, W., Selkoe, D. J., Kapogiannis, D., et al. (2019). miR-212 and miR-132 are downregulated in neurally derived plasma exosomes of Alzheimer's patients. Front. Neurosci. 13:1208. doi: $10.3389 /$ fnins.2019.01208

Chang, Y. W. Q. (2020). MicroRNA miR-212 regulates PDCD4 to attenuate Ab25-35-induced neurotoxicity via PI3K/AKT signaling modulation of a number miRNAs, such as miR-101a-3p, miR-9, miR-34a, miR-188, and miR-129, emphasizing further the impact of miRNAs in the progression of AD. However, these results should be verified in human subjects as well.

Few studies have shown the association between miRNA CNVs/ SNPs and the risk of AD. However, these results have not been verified in different ethnic groups. Re-assessment of the results of genome-wide association studies with a focus on noncoding regions might lead to the identification of further risk loci for this multifactorial condition.

Finally, a limitation of several functional investigations in this field is that they have assessed miRNA functions in cell lines such as HEK293 and SH-SY5Y, which are not true models of $\mathrm{AD}$.

\section{AUTHOR CONTRIBUTIONS}

MT and SG-F wrote the draft and revised it. MS, MH, and MG collected the data, designed the tables, and figures. All authors contributed to the article approved the submitted version.

pathway in Alzheimer's disease. Biotechnol. Lett. 42, 1789-1797. doi: 10.1007/s10529-020-02915-Z

Chen, F. Z., Zhao, Y., and Chen, H. Z. (2019). MicroRNA-98 reduces amyloid $\beta$-protein production and improves oxidative stress and mitochondrial dysfunction through the Notch signaling pathway via HEY2 in Alzheimer's disease mice. Int. J. Mol. Med. 43, 91-102. doi: 10.3892/ijmm.2018.3957

Chen, M., Li, L., Liu, C., and Song, L. (2020b). Berberine attenuates A $\beta$-induced neuronal damage through regulating miR-188/NOS1 in Alzheimer's disease. Mol. Cell. Biochem. 474, 285-294. doi: 10.1007/s11010-020-03852-1

Chen, W., Wu, L., Hu, Y., Jiang, L., Liang, N., Chen, J., et al. (2020a). MicroRNA-107 ameliorates damage in a cell model of Alzheimer's disease by mediating the FGF7/FGFR2/PI3K/Akt pathway. J. Mol. Neurosci. 70, 1589-1597. doi: 10.1007/s12031-020-01600-0

Cui, J. G., Li, Y. Y., Zhao, Y., Bhattacharjee, S., and Lukiw, W. J. (2010). Differential regulation of interleukin-1 receptor-associated kinase-1 (IRAK-1) and IRAK-2 by microRNA-146a and NF- $\kappa \mathrm{B}$ in stressed human astroglial cells and in Alzheimer disease. J. Biol. Chem. 285, 38951-38960. doi: 10.1074/jbc.M110.178848

Cui, L., Li, Y., Ma, G., Wang, Y., Cai, Y., Liu, S., et al. (2014). A functional polymorphism in the promoter region of microRNA-146a is associated with the risk of Alzheimer disease and the rate of cognitive decline in patients. PLoS ONE 9:e89019. doi: 10.1371/journal.pone.0089019

Deng, Y., Zhang, J., Sun, X., Ma, G., Luo, G., Miao, Z., et al. (2020). miR-132 improves the cognitive function of rats with Alzheimer's disease by inhibiting the MAPK1 signal pathway. Exp. Therapeutic Med. 20:1. doi: $10.3892 /$ etm.2020.9288

Denk, J., Oberhauser, F., Kornhuber, J., Wiltfang, J., Fassbender, K., Schroeter, M. L., et al. (2018). Specific serum and CSF microRNA profiles distinguish sporadic behavioural variant of frontotemporal dementia compared with Alzheimer patients and cognitively healthy controls. PLoS ONE 13:e0197329. doi: 10.1371/journal.pone.0197329

Duan, Q., and Si, E. (2019). MicroRNA-25 aggravates A 31 -42-induced hippocampal neuron injury in Alzheimer's disease by downregulating KLF2 via the Nrf2 signaling pathway in a mouse model. J. Cell. Biochem. 120, 15891-15905. doi: 10.1002/jcb.28861

El Fatimy, R., Li, S., Chen, Z., Mushannen, T., Gongala, S., Wei, Z., et al. (2018). MicroRNA-132 provides neuroprotection for tauopathies via multiple signaling pathways. Acta Neuropathol. 136, 537-555. doi: 10.1007/s00401-018-1880-5 
Fernández-de Frutos, M., Galán-Chilet, I., Goedeke, L., Kim, B., PardoMarqués, V., Pérez-García, A., et al. (2019). MicroRNA 7 impairs insulin signaling and regulates $\mathrm{A} \beta$ levels through posttranscriptional regulation of the insulin receptor substrate 2, insulin receptor, insulin-degrading enzyme, and liver X receptor pathway. Mol. Cell. Biol. 39, e00170-e0119. doi: 10.1128/MCB.00170-19

Gámez-Valero, A., Campdelacreu, J., Vilas, D., Ispierto, L., Reñé R, Álvarez, R., et al. (2019). Exploratory study on microRNA profiles from plasma-derived extracellular vesicles in Alzheimer's disease and dementia with Lewy bodies. Transl. Neurodegeneration 8:31. doi: 10.1186/s40035-019-0169-5

Geng, L., Zhang, T., Liu, W., and Chen, Y. (2018). Inhibition of miR-128 abates A $\beta$ mediated cytotoxicity by targeting PPAR- $\gamma$ via NF- $\mathrm{KB}$ inactivation in primary mouse cortical neurons and Neuro2a cells. Yonsei Med. J. 59, 1096-1106. doi: 10.3349/ymj.2018.59.9.1096

Ghanbari, M., Ikram, M. A., De Looper, H. W., Hofman, A., Erkeland, S. J., Franco, O. H., et al. (2016). Genome-wide identification of microRNArelated variants associated with risk of Alzheimer's disease. Sci. Rep. 6:28387. doi: $10.1038 /$ srep28387

Guo, J., Cai, Y., Ye, X., Ma, N., Wang, Y., Yu, B., et al. (2019). MiR-409$5 \mathrm{p}$ as a regulator of neurite growth is down regulated in APP/PS1 murine model of Alzheimer's disease. Front. Neurosci. 13:1264. doi: 10.3389/fnins.201 9.01264

Guo, R., Fan, G., Zhang, J., Wu, C., Du, Y., Ye, H., et al. (2017). A 9-microRNA signature in serum serves as a noninvasive biomarker in early diagnosis of Alzheimer's disease. J. Alzheimer's Dis. 60, 1365-1377. doi: 10.3233/JAD-1 70343

Han, C., Guo, L., Yang, Y., Guan, Q., Shen, H., Sheng, Y., et al. (2020). Mechanism of microRNA-22 in regulating neuroinflammation in Alzheimer's disease. Brain Behav. 2020:e01627. doi: 10.1002/brb3.1627

Han, L., Zhou, Y., Zhang, R., Wu, K., Lu, Y., Li, Y., et al. (2018). MicroRNA Let-7f-5p promotes bone marrow mesenchymal stem cells survival by targeting caspase-3 in alzheimer disease model. Front. Neurosci. 12:333. doi: $10.3389 /$ fnins.2018.00333

Hara, N., Kikuchi, M., Miyashita, A., Hatsuta, H., Saito, Y., Kasuga, K., et al. (2017). Serum microRNA miR-501-3p as a potential biomarker related to the progression of Alzheimer's disease. Acta Neuropathol. Commun. 5:10. doi: 10.1186/s40478-017-0414-z

He, B., Chen, W., Zeng, J., Tong, W., and Zheng, P. (2020). MicroRNA-326 decreases tau phosphorylation and neuron apoptosis through inhibition of the JNK signaling pathway by targeting VAV1 in Alzheimer's disease. J. Cell. Physiol. 235, 480-493. doi: $10.1002 /$ jcp.28988

Hernandez-Rapp, J., Rainone, S., Goupil, C., Dorval, V., Smith, P. Y., Saint-Pierre, M., et al. (2016). microRNA-132/212 deficiency enhances $A \beta$ production and senile plaque deposition in Alzheimer's disease triple transgenic mice. Sci. Rep. 6:30953. doi: 10.1038/srep30953

Higaki, S., Muramatsu, M., Matsuda, A., Matsumoto, K., Satoh J-i, Michikawa, M., et al. (2018). Defensive effect of microRNA-200b/c against amyloidbeta peptide-induced toxicity in Alzheimer's disease models. PLoS ONE 13:e0196929. doi: 10.1371/journal.pone.0196929

Hu, S., Wang, H., Chen, K., Cheng, P., Gao, S., Liu, J., et al. (2015). MicroRNA$34 \mathrm{c}$ downregulation ameliorates amyloid- $\beta$-induced synaptic failure and memory deficits by targeting VAMP2. J. Alzheimer's Dis. 48, 673-686. doi: 10.3233/JAD-150432

Hu, Y-K., Wang, X., Li, L., Du, Y-H., Ye, H-T., Li, C-Y. (2013). MicroRNA-98 induces an Alzheimer's disease-like disturbance by targeting insulin-like growth factor 1. Neurosci. Bulletin 29, 745-751. doi: 10.1007/s12264-013-1348-5

Huang, W., Wu, X., Xue, Y., Zhou, Y., Xiang, H., Yang, W., et al. (2020). MicroRNA-3614 regulates inflammatory response via targeting TRAF6-mediated MAPKs and NF- $\mathrm{KB}$ signaling in the epicardial adipose tissue with coronary artery disease. Int. J. Cardiol. 2020:45. doi: 10.1016/j.ijcard.2020.09.045

Iqbal, K., and Grundke-Iqbal, I. (2010). Alzheimer's disease, a multifactorial disorder seeking multitherapies. Alzheimers Dement. 6, 420-424. doi: 10.1016/j.jalz.2010.04.006

Jin, Y., Tu, Q., and Liu, M. (2018). MicroRNA-125b regulates Alzheimer's disease through SphK1 regulation. Mol. Med. Rep. 18, 2373-2380. doi: 10.3892/mmr.2018.9156
Kang, Q., Xiang, Y., Li, D., Liang, J., Zhang, X., Zhou, F., et al. (2017). MiR-124-3p attenuates hyperphosphorylation of Tau proteininduced apoptosis via caveolin-1-PI3K/Akt/GSK3 $\beta$ pathway in N2a/APP695swe cells. Oncotarget 8:24314. doi: 10.18632/oncotarge t.15149

Kim, J., Yoon, H., Horie, T., Burchett, J. M., Restivo, J. L., Rotllan, N., et al. (2015). microRNA-33 regulates ApoE lipidation and amyloid- $\beta$ metabolism in the brain. J. Neurosci. 35, 14717-14726. doi: 10.1523/JNEUROSCI.2053-15.2015

Kumar, S., Reddy, A. P., Yin, X., and Reddy, P. H. (2019). Novel MicroRNA-455$3 \mathrm{p}$ and its protective effects against abnormal APP processing and amyloid beta toxicity in Alzheimer's disease. Biochim. Biophys. Acta 1865, 2428-2440. doi: 10.1016/j.bbadis.2019.06.006

Kumar, S., and Reddy, P. H. (2018). MicroRNA-455-3p as a potential biomarker for Alzheimer's disease: an update. Front. Aging Neurosci. 10:41. doi: 10.3389/fnagi.2018.00041

Kumar, S., Vijayan, M., and Reddy, P. H. (2017). MicroRNA-455-3p as a potential peripheral biomarker for Alzheimer's disease. Hum. Mol. Genet. 26, 3808-3822. doi: $10.1093 / \mathrm{hmg} / \mathrm{ddx} 267$

Lee, K., Kim, H., An, K., Kwon O-B, Park, S., Cha, J. H., et al. (2016). Replenishment of microRNA-188-5p restores the synaptic and cognitive deficits in 5XFAD mouse model of Alzheimer's disease. Sci Rep. 6, 1-14. doi: 10.1038/srep34433

Li, F., Wei, G., Bai, Y., Li, Y., Huang, F., Lin, J., et al. (2015). MicroRNA574 is involved in cognitive impairment in 5-month-old APP/PS1 mice through regulation of neuritin. Brain Res. 1627, 177-188. doi: 10.1016/j.brainres.2015.09.022

Li, J., Li, D., Zhou, H., Wu, G., He, Z., Liao, W., et al. (2020a). MicroRNA-338-5p alleviates neuronal apoptosis via directly targeting BCL2L11 in APP/PS1 mice. Aging 12:10.18632. doi: 10.18632/aging.104005

Li, P., Xu, Y., Wang, B., Huang, J., and Li, Q. (2020b). miR-34a-5p and miR-125b$5 p$ attenuate $A \beta$-induced neurotoxicity through targeting BACE1. J. Neurol. Sci. 2020:116793. doi: 10.1016/j.jns.2020.116793

Li, S., Yan, Y., Jiao, Y., Gao, Z., Xia, Y., Kong, L., et al. (2016). Neuroprotective effect of osthole on neuron synapses in an Alzheimer's disease cell model via upregulation of MicroRNA-9. J. Mol. Neurosci. 60, 71-81. doi: 10.1007/s12031-016-0793-9

Li, S-H., Gao, P., Wang, L-T., Yan, Y-H., Xia, Y., Song, J., et al. (2017). Osthole stimulated neural stem cells differentiation into neurons in an Alzheimer's disease cell model via upregulation of microRNA-9 and rescued the functional impairment of hippocampal neurons in APP/PS1 transgenic mice. Front. Neurosci. 11:340. doi: 10.3389/fnins.2017.00340

Liang, C., Zhu, H., Xu, Y., Huang, L., Ma, C., Deng, W., et al. (2012). MicroRNA-153 negatively regulates the expression of amyloid precursor protein and amyloid precursor-like protein 2. Brain Res. 1455, 103-113. doi: 10.1016/j.brainres.2011.10.051

Liang, X., Wang, L., Wang, M., Liu, Z., Liu, X., Zhang, B., et al. (2020). MicroRNA-124 inhibits macrophage cell apoptosis via targeting p38/MAPK signaling pathway in atherosclerosis development. Aging 12:13005. doi: 10.18632 /aging. 103387

Lin, Y., Liang, X., Yao, Y., Xiao, H., Shi, Y., and Yang, J. (2019). Osthole attenuates APP-induced Alzheimer's disease through upregulating miRNA-101a-3p. Life Sci. 225, 117-131. doi: 10.1016/j.lfs.2019.04.004

Liu, C-G., Song, J., Zhang, Y-Q., and Wang, P-C. (2014a). MicroRNA-193b is a regulator of amyloid precursor protein in the blood and cerebrospinal fluid derived exosomal microRNA-193b is a biomarker of Alzheimer's disease. Mol. Med. Rep. 10, 2395-2400. doi: 10.3892/mmr.2014.2484

Liu, C-G., Wang, J-L., Li, L., and Wang, P-C. (2014b). MicroRNA-384 regulates both amyloid precursor protein and $\beta$-secretase expression and is a potential biomarker for Alzheimer's disease. Int. J. Mol. Med. 34, 160-166. doi: $10.3892 / \mathrm{ijmm} .2014 .1780$

Liu, D. Y., and Zhang, L. (2019). MicroRNA-132 promotes neurons cell apoptosis and activates Tau phosphorylation by targeting GTDC-1 in Alzheimer's disease. Eur. Rev. Med. Pharmacol. Sci. 23, 8523-32. doi: 10.26355/eurrev_201910_19166

Liu, F., Zhang, Z., Chen, W., Gu, H., and Yan, Q. (2018). Regulatory mechanism of microRNA-377 on CDH13 expression in the cell model of Alzheimer's disease. Eur. Rev. Med. Pharmacol. Sci. 22, 2801-8. doi: 10.26355/eurrev_201805_14979 Liu, H., Chu, W., Gong, L., Gao, X., and Wang, W. (2016b). MicroRNA-26b is upregulated in a double transgenic mouse model of Alzheimer's disease and 
promotes the expression of amyloid- $\beta$ by targeting insulin-like growth factor 1 . Mol. Med. Rep. 13, 2809-2814. doi: 10.3892/mmr.2016.4860

Liu, J., Zuo, X., Han, J., Dai, Q., Xu, H., Liu, Y., et al. (2020). MiR9-5p inhibits mitochondrial damage and oxidative stress in $\mathrm{AD}$ cell models by targeting GSK-3ß. Biosci. Biotechnol. Biochem. 84, 2273-2280. doi: 10.1080/09168451.2020.1797469

Liu, W., Cai, H., Lin, M., Zhu, L., Gao, L., Zhong, R., et al. (2016a). MicroRNA-107 prevents amyloid-beta induced blood-brain barrier disruption and endothelial cell dysfunction by targeting Endophilin-1. Exp. Cell Res. 343, 248-257. doi: 10.1016/j.yexcr.2016.03.026

Liu, W., Liu, C., Zhu, J., Shu, P., Yin, B., Gong, Y., et al. (2012). MicroRNA16 targets amyloid precursor protein to potentially modulate Alzheimer'sassociated pathogenesis in SAMP8 mice. Neurobiol. Aging 33, 522-534. doi: 10.1016/j.neurobiolaging.2010.04.034

Liu, Y., Zhang, Y., Liu, P., Bai, H., Li, X., Xiao, J., et al. (2019). MicroRNA-128 knockout inhibits the development of Alzheimer's disease by targeting PPAR $\gamma$ in mouse models. Eur. J. Pharmacol. 843, 134-144. doi: 10.1016/j.ejphar.2018.11.004

Long, J. M., Ray, B., and Lahiri, D. K. (2012). MicroRNA-153 physiologically inhibits expression of amyloid- $\beta$ precursor protein in cultured human fetal brain cells and is dysregulated in a subset of Alzheimer disease patients. J. Biol. Chem. 287, 31298-31310. doi: 10.1074/jbc.M112.366336

Long, J. M., Ray, B., and Lahiri, D. K. (2014). MicroRNA-339-5p downregulates protein expression of $\beta$-site amyloid precursor protein-cleaving enzyme 1 (BACE1) in human primary brain cultures and is reduced in brain tissue specimens of Alzheimer disease subjects. J. Biol. Chem. 289, 5184-5198. doi: 10.1074/jbc.M113.518241

Lukiw, W. J. (2007). Micro-RNA speciation in fetal, adult and Alzheimer's disease hippocampus. Neuroreport 18, 297-300. doi: 10.1097/WNR.0b013e3280148e8b

Ma, X., Liu, L., and Meng, J. (2017). MicroRNA-125b promotes neurons cell apoptosis and Tau phosphorylation in Alzheimer's disease. Neurosci. Lett.661, 57-62. doi: 10.1016/j.neulet.2017.09.043

Madadi, S., Saidijam, M., Yavari, B., and Soleimani, M. (2020). Downregulation of serum miR-106b: a potential biomarker for Alzheimer disease. Archiv. Physiol. Biochem. 2020, 1-5. doi: 10.1080/13813455.2020.1734842

Manzine, P. R., Pelucchi, S., Horst, M. A., Vale, F. A., Pavarini, S. C., Audano, M., et al. (2018). microRNA 221 Targets ADAM10 mRNA and is Downregulated in Alzheimer's Disease. J. Alzheimer's Dis. 61, 113-123. doi: 10.3233/JAD-170592

McKeever, P. M., Schneider, R., Taghdiri, F., Weichert, A., Multani, N., Brown, R. A., et al. (2018). MicroRNA expression levels are altered in the cerebrospinal fluid of patients with young-onset Alzheimer's disease. Mol. Neurobiol. 55, 8826-8841. doi: 10.1007/s12035-018-1032-x

Miao, J., Jing, J., Shao, Y., and Sun, H. (2020). MicroRNA-138 promotes neuroblastoma SH-SY5Y cell apoptosis by directly targeting DEK in Alzheimer's disease cell model. BMC Neurosci. 21, 1-8. doi: 10.1186/s12868-020-00579-z

Modi, P. K., Jaiswal, S., and Sharma, P. (2016). Regulation of neuronal cell cycle and apoptosis by microRNA 34a. Mol. Cell. Biol. 36, 84-94. doi: 10.1128/MCB.00589-15

Moncini, S., Lunghi, M., Valmadre, A., Grasso, M., Del Vescovo, V., Riva, P., et al. (2017). The miR-15/107 family of microRNA genes regulates CDK5R1/p35 with implications for Alzheimer's disease pathogenesis. Mol. Neurobiol. 54, 4329-4342. doi: 10.1007/s12035-016-0002-4

Müller, M., Jäkel, L., Bruinsma, I. B., Claassen, J. A., Kuiperij, H. B., and Verbeek, M. M. (2016). MicroRNA-29a is a candidate biomarker for Alzheimer's disease in cell-free cerebrospinal fluid. Mol. Neurobiol. 53, 2894-2899. doi: $10.1007 /$ s12035-015-9156-8

Nagaraj, S., Laskowska-Kaszub, K., Debski, K. J., Wojsiat, J., Dabrowski, M., Gabryelewicz, T., et al. (2017). Profile of 6 microRNA in blood plasma distinguish early stage Alzheimer's disease patients from non-demented subjects. Oncotarget 8:16122. doi: 10.18632/oncotarget.15109

O’Brien, J., Hayder, H., Zayed, Y., and Peng, C. (2018). Overview of microRNA biogenesis, mechanisms of actions, and circulation. Front. Endocrinol. 9:402. doi: 10.3389/fendo.2018.00402

Pan, J., Zhang, D., Zhang, J., Qin, P., and Wang, J. (2019). LncRNA RMRP silence curbs neonatal neuroblastoma progression by regulating microRNA-206/tachykinin-1 receptor axis via inactivating extracellular signal-regulated kinases. Cancer Biol. Therapy 20, 653-665. doi: 10.1080/15384047.2018.1550568

Prince, M., Bryce, R., Albanese, E., Wimo, A., Ribeiro, W., and Ferri, C. P. (2013). The global prevalence of dementia: a systematic review and metaanalysis. Alzheimer's Dement. 9, 63-75 e2. doi: 10.1016/j.jalz.2012.11.007

Qian, Q., Zhang, J., He F-P, Bao W-X, Zheng T-T, Zhou D-M, et al. (2019). Downregulated expression of microRNA-338-5p contributes to neuropathology in Alzheimer's disease. FASEB J. 33, 4404-44017. doi: 10.1096/fj.201801846R

Querfurth, H. W., and LaFerla, F. M. (2010). Alzheimer's disease. N. Engl. J. Med. 362, 329-344. doi: 10.1056/NEJMra0909142

Ren, R-J., Zhang, Y-F., Dammer, E. B., Zhou, Y., Wang, L-l., Liu, X-H., et al. (2016). Peripheral blood MicroRNA expression profiles in Alzheimer's disease: screening, validation, association with clinical phenotype and implications for molecular mechanism. Mol. Neurobiol. 53, 5772-5781. doi: 10.1007/s12035-015-9484-8

Salta, E., Sierksma, A., Vanden Eynden, E., and De Strooper, B. (2016). miR-132 loss de-represses ITPKB and aggravates amyloid and TAU pathology in Alzheimer's brain. EMBO Mol. Med. 8, 1005-1018. doi: 10.15252/emmm.201606520

Shu, B., Zhang, X., Du, G., Fu, Q., and Huang, L. (2018). MicroRNA-107 prevents amyloid- $\beta$-induced neurotoxicity and memory impairment in mice. Int. J. Mol. Med. 41, 1665-1672. doi: 10.3892/ijmm.2017.3339

So, J. B. Y., Kapoor, R., Zhu, F., Koh, C., Zhou, L., Zou, R., et al. (2020). Development and validation of a serum microRNA biomarker panel for detecting gastric cancer in a high-risk population. Gut 2020:322065. doi: 10.1136/gutjnl-2020-322065

Song, Y., Hu, M., Zhang, J., and Teng Z-q, Chen, C. (2019). A novel mechanism of synaptic and cognitive impairments mediated via microRNA-30b in Alzheimer's disease. EBioMedicine 39, 409-421. doi: 10.1016/j.ebiom.2018.11.059

Sun, W., Zhao, J., and Li, C. (2020). Dexmedetomidine provides protection against hippocampal neuron apoptosis and cognitive impairment in mice with Alzheimer's disease by mediating the miR-129/YAP1/JAG1 axis. Mol. Neurobiol. 57, 5044-5055. doi: 10.1007/s12035-020-02069-Z

Tan, L., Yu, J-T., Tan, M-S., Liu, Q-Y., Wang, H-F., Zhang, W., et al. (2014). Genome-wide serum microRNA expression profiling identifies serum biomarkers for Alzheimer's disease. J. Alzheimer's Dis. 40, 1017-1027. doi: 10.3233/JAD-132144

Tang, Y., Bao, J., Su, J., and Huang, W. (2017). MicroRNA-139 modulates Alzheimer's-associated pathogenesis in SAMP8 mice by targeting cannabinoid receptor type 2. Genet. Mol. Res. 16:19166. doi: 10.4238/gmr16019166

Vilardo, E., Barbato, C., Ciotti, M., Cogoni, C., and Ruberti, F. (2010). MicroRNA101 regulates amyloid precursor protein expression in hippocampal neurons. J. Biol. Chem. 285, 18344-18351. doi: 10.1074/jbc.M110.112664

Wang, G., Huang, Y., Wang L-L, Zhang Y-F, Xu, J., Zhou, Y., et al. (2016). MicroRNA-146a suppresses ROCK1 allowing hyperphosphorylation of tau in Alzheimer's disease. Sci. Rep. 6:26697. doi: 10.1038/srep26697

Wang, J., Chen, C., and Zhang, Y. (2020). An investigation of microRNA103 and microRNA-107 as potential blood-based biomarkers for disease risk and progression of Alzheimer's disease. J. Clin. Lab. Anal. 34:e23006. doi: $10.1002 /$ jcla.23006

Wang, L., Liu, J., Wang, Q., Jiang, H., Zeng, L., Li, Z., et al. (2019b). MicroRNA200a-3p mediates neuroprotection in Alzheimer-related deficits and attenuates amyloid-beta overproduction and tau hyperphosphorylation via coregulating BACE1 and PRKACB. Front. Pharmacol. 10:806. doi: 10.3389/fphar.2019.00806

Wang, M., Qin, L., and Tang, B. (2019a). MicroRNAs in Alzheimer's disease. Front. Genet. 10:153. doi: 10.3389/fgene.2019.00153

Wang, R., and Zhang, J. (2020). Clinical significance of miR-433 in the diagnosis of Alzheimer's disease and its effect on $A \beta$-induced neurotoxicity by regulating JAK2. Exp. Gerontol. 141:111080. doi: 10.1016/j.exger.2020.111080

Wang, X., Tan, L., Lu, Y., Peng, J., Zhu, Y., Zhang, Y., et al. (2015b). MicroRNA-138 promotes tau phosphorylation by targeting retinoic acid receptor alpha. FEBS Lett. 589, 726-729. doi: 10.1016/j.febslet.2015.02.001

Wang, X., Xu, Y., Zhu, H., Ma, C., Dai, X., and Qin, C. (2015a). Downregulated microRNA-222 is correlated with increased p27Kip1 expression in a double transgenic mouse model of Alzheimer's disease. Mol. Med. Rep. 12, 7687-7692. doi: $10.3892 / \mathrm{mmr} .2015 .4339$ 
Wang, Y., Luo, X., Liu, Y., Han, G., and Sun, D. (2019c). Long noncoding RNA RMRP promotes proliferation and invasion via targeting miR-1-3p in non-small-cell lung cancer. J. Cell. Biochem. 120, 15170-15181. doi: $10.1002 / j \mathrm{cb} .28779$

Wang, Y., Veremeyko, T., Wong AH-K, El Fatimy, R., Wei, Z., Cai, W., et al. (2017). Downregulation of miR-132/212 impairs S-nitrosylation balance and induces tau phosphorylation in Alzheimer's disease. Neurobiol. Aging 51, 156-166. doi: 10.1016/j.neurobiolaging.2016.12.015

Wang, Z., Qin, W., Wei, C., Tang, Y., Zhao, L., Jin, H., et al. (2018). The microRNA1908 up-regulation in the peripheral blood cells impairs amyloid clearance by targeting ApoE. Int. J. Geriatric Psychiatry 33, 980-986. doi: 10.1002/gps.4881

Wong, H-KA., Veremeyko, T., Patel, N., Lemere, C. A., Walsh, D. M., Esau, C., et al. (2013). De-repression of FOXO3a death axis by microRNA-132 and212 causes neuronal apoptosis in Alzheimer's disease. Hum. Mol. Genet. 22, 3077-3092. doi: 10.1093/hmg/ddt164

Wu, B. W., Wu, M. S., and Guo, J. D. (2018b). Effects of microRNA-10a on synapse remodeling in hippocampal neurons and neuronal cell proliferation and apoptosis through the BDNF-TrkB signaling pathway in a rat model of Alzheimer's disease. J. Cell. Physiol. 233, 5281-5292. doi: 10.1002/jcp.26328

Wu, D. M., Wen, X., Wang, Y. J., Han, X. R., Wang, S., Shen, M., et al. (2018a). Effect of microRNA-186 on oxidative stress injury of neuron by targeting interleukin 2 through the janus kinase-signal transducer and activator of transcription pathway in a rat model of Alzheimer's disease. J. Cell. Physiol. 233, 9488-9502. doi: 10.1002/jcp.26843

Wu, Q., Ye, X., Xiong, Y., Zhu, H., Miao, J., Zhang, W., et al. (2016). The protective role of microRNA-200c in Alzheimer's disease pathologies is induced by beta amyloid-triggered endoplasmic reticulum stress. Front. Mol. Neurosci. 9:140. doi: 10.3389/fnmol.2016.00140

Wu, Q., Yuan, X., Bai, J., Han, R., Li, Z., Zhang, H., et al. (2019). MicroRNA181a protects against pericyte apoptosis via directly targeting FOXO1: implication for ameliorated cognitive deficits in APP/PS1 mice. Aging 11:6120. doi: 10.18632/aging.102171

Xiao, X., Gu, Y., Wang, G., and Chen, S. (2019). c-Myc, RMRP, and miR$34 a-5 p$ form a positive-feedback loop to regulate cell proliferation and apoptosis in multiple myeloma. Int. J. Biol. Macromol. 122, 526-537. doi: 10.1016/j.ijbiomac.2018.10.207

Xie, B., Liu, Z., Jiang, L., Liu, W., Song, M., Zhang, Q., et al. (2017). Increased serum miR-206 level predicts conversion from amnestic mild cognitive impairment to Alzheimer's disease: a 5-year follow-up study. J. Alzheimer's Dis. 55, 509-520. doi: 10.3233/JAD-160468

Xing, H., Guo, S., Zhang, Y., Zheng, Z., and Wang, H. (2016). Upregulation of microRNA-206 enhances lipopolysaccharide-induced inflammation and release of amyloid- $\beta$ by targeting insulin-like growth factor 1 in microglia. Mol. Med. Rep. 14, 1357-1364. doi: 10.3892/mmr.2016.5369

Xu, N., Li A-D, Ji L-L, Ye, Y., and Wang Z-Y, Tong, L. (2019). miR-132 regulates the expression of synaptic proteins in APP/PS1 transgenic mice through C1q. Eur. J. Histochem. 63:3008. doi: 10.4081/ejh.2019.3008

Yang, G., Song, Y., Zhou, X., Deng, Y., Liu, T., Weng, G., et al. (2015). DNA methyltransferase 3, a target of microRNA-29c, contributes to neuronal proliferation by regulating the expression of brain-derived neurotrophic factor. Mol. Med. Rep. 12, 1435-1442. doi: 10.3892/mmr.2015.3531

Yang, K., Feng, S., Ren, J., and Zhou, W. (2019a). Upregulation of microRNA196a improves cognitive impairment and alleviates neuronal damage in hippocampus tissues of Alzheimer's disease through downregulating LRIG3 expression. J. Cell. Biochem. 120, 17811-17821. doi: 10.1002/jcb.29047

Yang, Q., Zhao, Q., and Yin, Y. (2019b). miR-133b is a potential diagnostic biomarker for Alzheimer's disease and has a neuroprotective role. Exp. Therapeutic Med. 18, 2711-2718. doi: 10.3892/etm.2019.7855

Yilmaz, S. G., Erdal, M. E., Özge, A. A., and Sungur, M. A. (2016). Can peripheral MicroRNA expression data serve as epigenomic (upstream) biomarkers of Alzheimer's disease? Omics 20, 456-461. doi: 10.1089/omi.2016.0099
Yu, L., Li, H., Liu, W., Zhang, L., Tian, Q., Li, H., et al. (2020). MiR-485-3p serves as a biomarker and therapeutic target of Alzheimer's disease via regulating neuronal cell viability and neuroinflammation by targeting AKT3. Mol. Genet. Genom. Med. 2020:e1548. doi: 10.1002/mgg3.1548

Yuan, J., Wu, Y., Li, L., and Liu, C. (2020). MicroRNA-425-5p promotes tau phosphorylation and cell apoptosis in Alzheimer's disease by targeting heat shock protein B8. J. Neural Transmission. 2020, 1-8. doi: 10.1007/s00702-019-02134-5

Zeng, Z., Liu, Y., Zheng, W., Liu, L., Yin, H., Zhang, S., et al. (2019). MicroRNA-129-5p alleviates nerve injury and inflammatory response of Alzheimer's disease via downregulating SOX6. Cell Cycle 18, 3095-3110. doi: 10.1080/15384101.2019.1669388

Zhang, B., Wang, A., Xia, C., Lin, Q., and Chen, C. (2015). A single nucleotide polymorphism in primary-microRNA-146a reduces the expression of mature microRNA-146a in patients with Alzheimer's disease and is associated with the pathogenesis of Alzheimer's disease. Mol. Med. Rep. 12, 4037-4042. doi: $10.3892 / \mathrm{mmr} .2015 .3968$

Zhang, S. Y., Huang, S. H., Gao, S. X., Wang, Y. B., Jin, P., and Lu, F. J. (2019). Upregulation of IncRNA RMRP promotes the activation of cardiac fibroblasts by regulating miR-613. Mol. Med. Rep. 20, 3849-3857. doi: 10.3892/mmr.2019.10634

Zhang, Y., Li, Q., Liu, C., Gao, S., Ping, H., Wang, J., et al. (2016a). MiR-214$3 \mathrm{p}$ attenuates cognition defects via the inhibition of autophagy in SAMP8 mouse model of sporadic Alzheimer's disease. Neurotoxicology 56, 139-149. doi: 10.1016/j.neuro.2016.07.004

Zhang, Y., Xing, H., Guo, S., Zheng, Z., Wang, H., and Xu, D. (2016b). MicroRNA$135 \mathrm{~b}$ has a neuroprotective role via targeting of $\beta$-site APP-cleaving enzyme 1 . Exp. Therapeut. Med. 12, 809-814. doi: 10.3892/etm.2016.3366

Zhao, X., Kang, J., Svetnik, V., Warden, D., Wilcock, G., David Smith, A., et al. (2020). A machine learning approach to identify a circulating MicroRNA signature for Alzheimer disease. J. Appl. Lab. Med. 5, 15-28. doi: 10.1373/jalm.2019.029595

Zhao, Z-B., Wu, L., Xiong, R., Wang L-L, Zhang, B., Wang, C., et al. (2014). MicroRNA-922 promotes tau phosphorylation by downregulating ubiquitin carboxy-terminal hydrolase L1 (UCHL1) expression in the pathogenesis of Alzheimer's disease. Neuroscience 275, 232-237. doi: 10.1016/j.neuroscience.2014.06.013

Zhou, H., Zhang, R., Lu, K., Yu, W., Xie, B., Cui, D., et al. (2016). Deregulation of miRNA-181c potentially contributes to the pathogenesis of $\mathrm{AD}$ by targeting collapsin response mediator protein 2 in mice. J. Neurol. Sci. 367, 3-10. doi: 10.1016/j.jns.2016.05.038

Zhou, Y., Chen, Z., Chen, A., Ma, J., Qian, J., and Ge, J. (2020). Elevated serum miR-133a predicts patients at risk of periprocedural myocardial injury after elective percutaneous coronary intervention. Cardiol. J. 2020:34. doi: 10.5603/CJ.a2020.0034

Zhu, H-C., Wang, L-M., Wang, M., Song, B., Tan, S., Teng, J-F., et al. (2012). MicroRNA-195 downregulates Alzheimer's disease amyloid$\beta$ production by targeting BACE1. Brain Res. Bulletin 88, 596-601. doi: 10.1016/j.brainresbull.2012.05.018

Conflict of Interest: The authors declare that the research was conducted in the absence of any commercial or financial relationships that could be construed as a potential conflict of interest.

Copyright (c) 2021 Samadian, Gholipour, Hajiesmaeili, Taheri and Ghafouri-Fard. This is an open-access article distributed under the terms of the Creative Commons Attribution License (CC BY). The use, distribution or reproduction in other forums is permitted, provided the original author(s) and the copyright owner(s) are credited and that the original publication in this journal is cited, in accordance with accepted academic practice. No use, distribution or reproduction is permitted which does not comply with these terms. 